\title{
The Being and Essence of the Human Soul in al-Taftāzānī's Thought
}

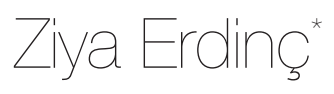

\begin{abstract}
Scholars in Islamic thought have examined the question of the human soul's essence through its various aspects and asserted diverse approaches. Unlike the earlier Islamic theologians (al-mutaqaddimün), the later Islamic theologians (almuta'akhkhirün) generally did not explicitly express their opinions on the essence of the human soul within the chapters discussing this issue because of their distinctive method and discussion style pertaining to the works in that period. Al-Taftāzāni, who is among the foremost Islamic theologians of the later period of kaläm, wrote statements indicating his acceptance of the concept of corporeal soul in his works' chapters on the human soul. However, he also included statements implying the idea of the immaterial soul in these same chapters. Analyzing Taftāzānīss opinions about the varied topics with which his thought system was involved is essential for determining his views on the essence of the human soul. By examining his thought system, this article has concluded Taftāzānī to have argued the human soul to self-evidently exist beyond the sensible body and to have preferred the view of the subtle body as identical to other bodies in terms of essence within the diversified views of corporeal soul. Moreover, he considered the essential parts (al-ajzä' al-așliyya), which he had predicated to most Islamic theologians as a view on the essence of the human soul, not as the essence of the human soul but as the basis of the sensible body. This article traces Taftāzānīs thoughts on the human soul through his views on physics, epistemology, ontology, and theology then reveals his opinions on the essence of the human soul based on these findings.
\end{abstract}

Keywords: Essence of the human soul, the being of the human soul, the subtle body, essential parts, immaterial human soul, al-Taftāzānī's thought

* This study is based on my PhD dissertation titled "Teftâzânîde Bilgi Teorisi” (al-Taftāzānī`s Theory of Knowledge) conducted at The Institute of Social Sciences of Sakarya University. I should acknowledge Prof. Dr. Robert Wisnovsky and Prof. Dr. Ramazan Biçer for their supervisions and TUBITAK and ISAM to support my research.

*** Asst. Prof., Ziya Erdinç, Sakarya University Faculty of Theology, The Department of Kalam. 


\section{Introduction}

he essence of the human soul is an issue Islamic theologians (mutakallimūn) have always researched. The ancients mutakallimūn (al-mutaqaddimūn)

L generally defended the corporeal soul, as was more compatible with their understanding of physics, and clearly expressed their views on this issue in their works. When based only on the chapters discussing the soul, however, uncovering the opinions of the later mutakallimūn (al-muta'akhkhirūn) regarding the essence of the human soul is complicated. ${ }^{1}$ Although the later Islamic theologians examined the immateriality and corporeality of the soul, they concluded in these chapters that the evidence from both sides was weak and avoided making a definitive judgment as to which side they preferred. Unlike most al-mutaqaddimūn, who had firmly denied immaterial being apart from God, al-muta'akhkhirūn considered their existence to be possible, saying that the arguments on which the denial of incorporeal substances is based are weak. Therefore, al-muta'akhkhirūn considered that one can not justify an approach asserting one of two general views on the soul to be necessary and the other to be impossible based on the definitive proofs. Although these mutakallimūn accepted the impossibility of proving one view definitively, no one can expect both main views to synchronously concord with their thought system. Therefore, to clarify al-muta'akhkhirūn's opinions on the human soul, how their conceptualization of the soul extended into their systems of thought should be tracked and researched by integrating them with their views on relevant issues.

Sa 'd al-Dīn al-Taftāzānī (d. 792/1390), one of the leading mutakallimūn in almuta'akhkhirūn's period, discussed the human soul and its essence in detail. In

1 Islamic philosophers and al-mutakallimūn generally used the terms al-nafs and al-rūh to express the essence of man. See Muhammad ibn Muhammad Abū Ḥāmid al-Ghazālī, Ma ârij al-quds fĩ madārij ma 'rifat al-mafs (Beirut: Dār al-Āfāq al-Jadīda, 1975), 15-18; Muhammad ibn Muḥammad Abū Hāmid al-Ghazālī, Ihyyā' 'ulūm al-dîn (Jeddah: Dār al-Minhāj, 1432), V, 13-19; Abū 'Abd Allāh Shams al-Dīn Muḥammad b. Abī Bakr Ibn al-Qayyim al-Jawziyya, Kitāb al-Rūḥ, ed. Muḥammad Ajmal al-Iṣlāḥī (Mecca: Dār 'Ālam al-Fawā' id, 1432), II, 517ff; Ömer Türker, "Nefis," in TDV İslâm Ansiklopedisi (Ankara: TDV Publications, 2006), 529; Murtaza Korlaelçi, “Gazzâlînnin İnsan Anlayışı,” in 900. Vefat Yılında İmam Gazzâlî: Milletlerarası Tartışmalı İlmî Toplantı (İstanbul: Marmara Üniversitesi İlahiyat Fakültesi Vakfı Publications, 2012), 765; Ali Durusoy, İbn Sînâ Felsefesinde İnsan ve Alemdeki Yeri : Nefs, Akıl ve Ruh (İstanbul: Marmara Üniversitesi İlahiyat Fakültesi Vakfı Publications, 2012), 34-39. Taftāzānī also used the terms al-nafs al-insānī, al-nafs, and al-rūh to indicate the essence of man. That`s why I will use these terms in current study in the same sense. Also I will use "the body" to mean al-jism and "the sensible body" for al-badan or al-badan al-maḥșūs. See Sa 'd al-Dīn Mas ūd b. 'Umar b. 'Abd Allāh al-Taftāzānī, Sharḥ al-Maqāṣid fí 'ilm al-kalām (İstanbul, 1305), I, 235; II, 27ff, 211-17, 220-21. 
his works' chapter devoted to the essence of the human soul, some statements show him to have adopted the concept of the corporeal soul. At the same time, other explanations are suitably understood as him acknowledging the idea of the abstracted soul. Therefore, tracking its projections in Taftāzānī's system of thought would be more accurate for correctly determining his view on the soul. Namely, I must endeavor to reveal his view on the essence of the soul by considering his thought system as a whole. In this context, this study firstly examines how Taftāzāni interpreted the inherited tradition on the issue in a way that would lay the groundwork for his approach and then outlines the view he adopted. Finally, the study elaborates on how this view was found based on its projections in his system of thought.

\section{The Existence of the Human Soul}

Drawing a line between the discussions on the existence and essence of a being researched is essential to attain accurate inferences. Examining the existence of the soul in Islamic thought was conducted on the basis of the following questions: Does man consist of only the sensible body? Is there a substance (i.e., a subtle body or abstract substance) beyond this sensible body (badan/al-badan al-mahsūs)? Does man consist of the sensible body and a substance beyond it? Accepting that man consists of only this sensible body basically means the human soul identifies with the body or is reduced to the body. Moreover, such an acceptance has the meaning of denying the existence of the human soul. However, if one defends the presence of another substance in humans beyond or intrinsic to the sensible body, that person genuinely accepts the existence of the soul.

Fakhr al-Dīn al-Rāzì (d. 606/1210) stated the existence of the entity indicated by the word "I" to be self-evident (badīhì). As logical possibilities, this entity could be a material substance (same as the sensible body or beyond it), an accident that is subsisted in the sensible body, or an immaterial substance. Knowing what possibility is true is not self-evident but is acquired through proof. In that case, according to Rāzì, while the existence of the soul is self-evident, whether it is a substance beyond the sensible body or not is not self-evident knowledge. ${ }^{2}$ Namely, Rāzì argued that one has to rely on the evidence to show the wrongness of the 
view that asserts sameness of the soul and the sensible body, which means the denial of the soul's existence as I mentioned previously, or to prove the existence of a soul beyond the sensible body. Shams al-Dinn al-Samarqandì (d. 722/1322) also continued Rāzì's approach. ${ }^{3}$

Contrary to the approach mentioned earlier, Taftāzānī held that not only the existence of what is indicated by the word "I" but also what is beyond the sensible body (warā' hāzā al-haykal al-maḩsūs) is self-evident. The human necessarily has self-knowledge. As will be discussed later, the differentiation between Taftāzānī and former theologians such as Rāzī and Samarqandī resulted from their different interpretations of the inherited tradition about the existence and essence of the soul. According to Taftāzānī, a soul must exist beyond the constantly changeable, dispersible, and sensible body (al-haykal al-mahsūs). The existence of the soul is necessarily as known as the definitive divine texts (al-naș al-qat ${ }^{`} \grave{\imath}$ ) testifying to the existence of a soul beyond the sensible body. ${ }^{4}$ To explain the existence of the soul, theologians relied on texts and "intellectual admonitions" (al-tanbīhāt al-'aqliyya). ${ }^{5}$ Therefore, according to Taftāzānī, there is no need for a proof for justifying the existence of the soul beyond the sensible body. However, one can only indicate and confirm its existence using some intellectual admonitions that act to uncover the thin veil over the issue by relying on the religious texts. Sometimes the self-evident judgments may be partially closed to understanding. The evidentiary explanations of this type of judgment are considered as admonitions, not proofs. ${ }^{6}$ In this context, Taftāzāni mentions three intellectual admonitions that show the existence of the soul. First, although the human body including its external and internal organs is constantly changing, the human remains human. Secondly, while a rational person can sometimes be unaware of the entire sensible body and its organs, they are never unaware of their existence. Thirdly, humans desire things contrary to their nature, such as ascending to the sky despite the sensible body being a hinderance. ${ }^{7}$

Shams al-Dīn al-Samarqandī, al-Ṣahā if al-ilāhiyya, ed. Aḥmad al-Sharīf (Kuwait: Maktaba al-Falāḥ, 1985), 272ff.

4 al-Taftāzānī, Sharḥ al-Maqāṣid, II, 29; Ziya Erdinç, “Teftâzânîde Bilen Bir Özne Olarak İnsan,” in İnsan Nedir? İslam Düşüncesinde İnsan Tasavvurları, ed. Ömer Türker and İbrahim Halil Üçer (Ankara: İLEM Publications, 2019), 245ff.

5 al-Taftāzānī, Sharḥ al-Maqāṣid, II, 29.

6 al-Taftāzānī, Sharḥ al-Maqāṣid, I, 60, 140.

7 al-Taftāzānī, Sharh al-Maqāṣid, II, 29. While Ibn Sīnā introduced some of these arguments to prove the immateriality of the human soul, theologians such as Rāzì and Samarqandī mentioned the same arguments to argue that the human soul is not identical to the sensible body. See Avicenna, Kitāb al-Nafs, ed. Fazlur Rahman (London: University of Durham, 1959), 252-57; Fakhr al-Dīn Abū 'Abd 
If the human only consists of the sensible body, they would not desire something unsuitable for the sensible body's structure.

For Taftāzānī, philosophers who accept the existence of the human soul based its existence on the species form (al-șüra al-naw 'iyya). Just as the species occurs by differentia being added to genus, the human species emerge from the soul's connection to the sensible body in the external realm. For a human to come into existence, the species form must be connected to matter. Although the human species is physically the same as other species, an incorporeal principle must be present that differentiates it from others. Again, very different actions are seen to emit from the sensible body. A principle must exist that is convenient for the source of these actions. To philosophers, this principle and species form is the soul (al-nafs). ${ }^{8}$ However, unlike philosophers, theologians explained the existence of the soul based on divine texts and intellectual admonitions as they did not consider the soul to be a species-making difference (fașl munawwi ${ }^{i}$ ). They attributed the actions that emerge from the sensible body to God instead of to the human soul. ${ }^{9}$ Taftāzāni appears to have considered the idea of the existence of the soul being sensible body as self-evident, which he also admitted, as a view the majority of theologians indeed defended.

\section{Opinions on the Essence of the Human Soul}

Islamic scholars started to discuss the essence of human from very early times. They have put forward different approaches to the nature of the human soul in concordance with their systems of thought. Sometimes differences also were found in how to understand and interpret the inherited approaches. To understand the thoughts of a scholar whose views are being examined, showing how he interprets the inherited tradition and revealing his different comments on scholarly heritage are crucial.

Allāh Muhammad Ibn 'Umar al-Rāzī, al-Arba'în fí 'ușūl al-dīn (Cairo: Maktaba al-Kulliyyāt al-Azhariyya, 1986), II, 18-24; al-Samarqandī, al-Ṣahă 'if, 272. The way Taftāzānī discussed these arguments is different from the forenamed scholars. As it is examined in detail here and in the following pages, since he already considers the soul being beyond the sensible body to be self-evident, he thinks they are intellectual admonitions for this self-evident truth. To him, the soul being beyond the body is not exclusive to the view of immaterial substance, which the philosophers defended. On the contrary, one can argue the soul being beyond the sensible body to be corporeal.

8 al-Taftāzānī, Sharḥ al-Maqāṣid, II, 27ff; cf. Avicenna, Kitāb al-Nafs, 4-12.

9 al-Taftāzānī, Sharḥ al-Maqāṣid, II, 29. 
Prior to Taftāzānī, Rāzì, who is a prominent thinker in the period of almuta'akhkhirūn, classified the approaches to the essence of the human soul in the most detailed way and had examined those advocating the views. Shams al-Din al-Samarqandī, a critical follower of Rāzì, classified these views almost the same as Rāzī. ${ }^{10}$ Therefore, Rāzī's approach should be addressed before moving on to Taftāzānī`s classification.

Rāzi stated three logical possibilities for the essence of the human, whose existence is necessarily known and indicated by the word "I": (i) the body (jism), (ii) an accident which spreads to the body, and (iii) neither the body nor an accident spreading to the body. The first view (i) is divided into three: (i.i) the being is the same as the sensible body itself, (i.ii) another body exists intrinsic to the sensible body, and (i.iii) a body exists entirely outside the sensible body. The view stating another body exists intrinsic to the body (i.ii) has also been subdivided into eight different views: (i.ii.i) four humours (akhlāț arba'a), (i.ii.ii) blood, (i.ii.iii) subtle blood, (i.ii.iv) spirit that ascends from the heart to the brain, (i.ii.v) atom, (i.ii.vi) a luminous and essentially living body differentiated from the other body in terms of essence, (i.ii.vii) a human's essential parts (al-ajza' al-așliyya) that are maintained from the beginning of his life to the end and (i.ii.viii) the essential organs without which a human cannot come into existence. ${ }^{11}$ For Rāzī, View (ii), which suggests the soul to be an accident, is not an idea a rational person would defend. Meanwhile, no one has presented View (i.iii) where the human soul is a body outside the sensible body; it has only been mentioned in the classification as a logical possibility. ${ }^{12}$

As for Taftāzānī, he considered the existence of a soul beyond the sensible body to be what religious texts and intellectual admonitions supported. He stated the schools of thought to have distinct views on the essence of the soul. For him, not only is the existence of the soul self-evident but so is its being beyond the sensible body. However, no certainty exists for the signification of the verses as to whether its essence is an immaterial substance or a body. The verses indicate humans' essence to be a substance different from this changing and transforming sensible body. ${ }^{13}$ Therefore, someone have to accept the soul as being beyond the sensible body and may see this soul as an immaterial substance or a corporeal subject when they consider the divine texts.

10 al-Samarqandī, al-Șahā 'if, 272-82.

11 al-Rāzī, al-Mațālib, VII, 35ff; al-Rāzī, al-Arbaînn, II, 18-27; İskenderoğlu, "Fakhr al-Din al-Razi on the Immateriality of the Human Soul," $122 \mathrm{ff}$.

12 al-Rāzì, al-Mațālib, VII, 35, 37ff.

13 Sa 'd al-Dīn Mas'ūd b. 'Umar b. 'Abd Allāh al-Taftāzānī, "al-Maqāṣid," in Sharh al-Maqāṣid (İstanbul: Mațba a al-Ḥājj Muharram Efendi al-Bosnawī, 1305), II, 29. 
According to Taftāzānī, the views put forward regarding the essence of the soul are as follows: (1) fire in the sensible body, (2) air, (3) water, (4) the four elements (spiritual), (5) the four humors, (6) specific humoral temperament (mizāj), (7) an atom in the heart, (8) essential parts, (9) the subtle body differentiating from other bodies in terms of essence, (10) the subtle body emerging in the heart, and (11) the immaterial soul. After mentioning these views on the essence of the soul, he discusses the arguments of two main groups: those who argue the materiality of the soul and those who argue the soul to be an immaterial substance. However, he does not separately examine the arguments of each of the eleven views. ${ }^{14}$ Instead, he shows his evaluations of the first ten views, each of which asserts the materiality of the soul within the view of the material soul. He comments on the view of the immaterial soul (11) by referencing "the soul to be connected with the sensible body in terms of management (tadbir) and control (tașarruf), though it is immaterial in itself." ${ }^{15}$ We see that Taftāzānī, with the view of the immaterial soul that he ascribes to the Islamic philosophers and some mutakallimūn, means an immateriality in the sense that the soul has an immaterial nature in itself, not an immateriality in the sense that the soul has no direct connection with the processes of material perception.

Taftāzānī's classification makes no mention of two of the views in Rāzī's classification: View (i.iii), which Rāzī included only as a logical possibility, and View (ii) which Rāzì stated no rational person would defend. This is because, unlike Rāzī, Taftāzānī tried to present the asserted views on the subject rather than make a logical classification. By considering the soul being beyond the sensible body to be self-evident, Taftāzānī does not give place View (i.i), which assumed the soul is identical to the sensible body, in his classification, whereas Rāzì did include this view.

Taftāzānì is seen to discuss the views on the material soul and the immaterial soul after explaining the soul to be beyond the sensible body. He considered both the material and the immaterial soul to be able to exist beyond the sensible body. The immaterial soul, which has an entirely different structure from the sensible body, is clearly beyond it. But how can a material soul that has the same structure as the sensible body be understood as being beyond the body? Taftāzānī considers what is perceived and felt by the senses to be the sensible body, while the human soul, even if it is corporeal, is neither felt nor perceived by the sense organs, as I 
will show in the forthcoming chapters. So, for the proponent of soul's corporeality, its being beyond the sensible body means that the soul is intrinsic to the body and cannot be perceived through the senses. If the soul were not intrinsic to the sensible body, it would not remain as itself while all parts of the sensible body were changing.

\subsection{The View of the Material Soul}

Those who argue the human soul to have a material structure assert different opinions on the nature of the corporeal soul. As seen in Rāzì and Taftāzānì's classifications, about ten different views are mentioned.

Examining all views on the corporeal soul in detail would exceed the limits of this study. For this reason, I am going to emphasize three views that are extremely important for the study. These opinions became famous in the literature and are attributed to al-mutakallimūn. Taftāzānī also placed significant emphasis on these following views: the structure, the essential parts, and the subtle body.

\subsubsection{The Structure View}

One of the essential views within the scope of the material soul is the expression of the sensible statue (al-haykal al-mahsūs), the specific structure (al-bunya almakhșuss), and the sensible/perceiving structure (al-bunya al-mahsūs). Although these views are attributed to theologians, scholars have interpreted these under different meanings. Some scholars have commented al-bunya al-mahsūs as the visible and sensible structure, while others hold it to mean the perceiving subject intrinsic to the sensible body.

In the classification presented in al-Arba īn and al-Mațālib, Rāzī attributed View (i.i), in which the soul is identical to the sensible body, as belonging to the majority of humans and many (kathīr/akthar) of al-mutakallimūn. To explain this view, he also uses the concept of sensible statue. ${ }^{16}$ In Muhașșal, he mentions the view many of al-mutakallimūn have as "the soul being this sensible structure." ${ }^{17}$ Namely, while using both concepts of sensible statue and sensible structure, he ascribes this views to many al-mutakallimūn. If his comments are accurate, most theologians would

17 Fakhr al-Dīn Abū 'Abd Allāh Muḥammad Ibn 'Umar al-Rāzī, Muḥașṣal afkār al-mutaqaddimīn wa almuta 'akhkhirīn min al-'ulamā' wa al-hukamā' wa al-mutakallimīn, ed. Ṭāhā 'Abd al-Ra' ūf Sa 'd (Cairo: Maktabat al-Kulliyyāt al-Azhariyya, n.d.), 223. 
have denied the existence of a soul beyond the sensible body and have adopted a strict monistic view that assumes a human to consist only of the sensible body. The proofs Rāzì presented on the incorrectness of this view also show that he used al-haykal al-mahsūs and al-bunya maḥsūs to mean the body as something sensible. ${ }^{18}$ Shams al-Dìn al-Samarqandī, like Rāzì, commented on both terms as meaning the soul to be the same as the sensible body and attributed this view as belonging to many of al-mutakallimūn. Again, he followed Rāzì for presenting proofs showing this view to be incorrect. ${ }^{19}$

The basis of Rāzīs interpretation is seen among the literature of almutaqaddimūn. The leading theological and heresiographical (maqālāt) works in the period of al-mutaqaddimūn ascribed to $\mathrm{Mu}^{\text {' }}$ tazilī scholars the view that a human consists of only the sensible body. These works in the early period explained that Mu'tazilī scholars such as Abū al-Hudhayl al-'Allāf (d. 235/849), Abū 'Alī alJubbā’̄ì (d. 303/916), Abū Hāshim al-Jubbā’ì (d. 321/933), and Qāḍī 'Abd al-Jabbār al-Hamadānī (d. 415/1025) considered a human as being comprised of the sensible body. ${ }^{20}$ In his explanations 'Abd al-Jabbār argued humans to consist of a specific structure and life. In this context, he identified the soul with the sensible body and

al-Rāzì, al-Arbaìn, II, 18-24; al-Rāzī, Muhașșal, $223 \mathrm{ff.}$

al-Samarqandī, al-Șahā if, 272; Shams al-Dīn al-Samarqandī, İ̀m al-āfāq wa-l-anfus (İstanbul: Türkiye Yazma Eserler Kurumu Başkanlığı Publications, 2020), 379ff; Ramazan Biçer, "Şemseddin Semerkandîye Göre İnsan Psikolojisinin Temel Nitelikleri," in Al Farabi IV. International Congress On Social Sciences: Congress Full Text Book, eds. Özlem Ülger and Atabek Movlyanov (İksad Publications, 2019), 18-24.

Abu'l-Qāsem al-Balkhī al-Ka 'bī, Kitāb al-Maqālāt wa ma'ahu 'Uyūn al-masā 'il wa al-jawābāt, eds. Hüseyin Hansu and Rājih Abdulhamīd Kurdī (Istanbul and Amman: KURAMER and Dār al-Fath, 2018), 461; Abū al-Ḥasan al-Ash arī, Maqālat al-Islāmīyīn wa-ikhtilāf al-mușallīn, eds. Ömer Aydın and Mehmet Dalkılıç (İstanbul: Türkiye Yazma Eserler Kurumu Başkanlığı Publications, 2019), 463; Yunus Cengiz, "Two Competing Approaches in the Mu'tazilite View of the Human Being: The Traditions of Abū alHudhayl and al-Nażām," Nazariyat Journal for the History of Islamic Philosophy and Sciences 4, no. 2 (April 2018): 59, 64ff. According to Qāḍī 'Abd al-Jabbār, man is the person with specific structure that distinguishes him from other beings. If a being has this specific structure, it is called "human." In this sense, even if a statue has the specific structure of the human, it cannot be described as human because it is not alive. Man is himself with all the parts that constitute the body. What is meant by the parts of the body are "the alive parts adjoined to the whole." Accordingly, blood, hair, nails and saliva are not part of the human body since they are not living beings. Therefore, they cannot also be a part of the human being. Similarly, most non-living bones are not part of the body. See Qādị 'Abd al-Jabbār, alMughnī fì abwāb al-tawhìd wa al-'adl: al-taklīf, ed. Muhammad 'Ali al-Najjār and 'Abd al-Hạlīm al-Najjār, vol. XI (Cairo, n.d.), 311ff, 331; Margaretha T. Heemskerk, “'Abd al-Jabbār al-Hamadhānī on Body, Soul and Resurrection," in A Common Rationality: Mu 'tazilism in Islam and Judaism, ed. Camilla Adang, Sabine Schmidtke, and David Sklare (Würzburg: Ergon Verlag in Kommission, 2007), 127-34; Cengiz, "Two Competing Approaches in the Mu'tazilite View of the Human Being: The Traditions of Abū alHudhayl and al-Nażzām," 64ff. 
did not accept the existence of a substance beyond the sensible body. Although he admitted the existence of a spirit (rüḥ) resembling breath and wind, he refused the idea of this spirit possessing life. Also, this spirit is neither the essence of a human itself nor a part of it. ${ }^{21}$

Unlike previous scholars, some theologians stated this for reference to the view on structure toward the essential parts of the sensible body, the parts that are intrinsic to it but not the body itself. For example, Mu'tazilī scholar Ibn al-Malāhimī al-Khuwārazmī (d. 536/1141), who argued the essence of man to be the specific structure, stated in reply to the criticisms of this view the essence that makes man itself to be the essential parts. This means the view of a specific structure is the same as the view of the essential parts. To al-Khuwārazmī, while a person's parts that constantly change throughout life are superfluous parts, the parts that are maintained without changing and that make a human a human are the essential parts. ${ }^{22}$ Another Mu 'tazilī scholar, Taqī al-Dīn al-Najrānī (d. 7th/13th century) cited the view of the essential parts to Abū 'Alī al-Jubbā'î, Abū Hāshim al-Jubbā'î and Qāḍī 'Abd al-Jabbār al-Hamadānī. Al-Najrānī knew that they had adopted the view of specific structure. That demonstrates al-Najrānī interpreted the view of structure as the essential parts. ${ }^{23}$

Nașir al-Dīn al-Ṭūsī (d. 672/1274) was another scholar who argued theologians to have meant the essential parts when using the term "the specific structure." ${ }^{24} \mathrm{Al}-$ Ṭūsī considered Rāzī's interpretation of the maḥsūs, which is an adjective of structure in the phrase al-haykal/al-bunya al-mahsūs, in the sense of "sensible" entities such as color and shape to be false. According to Ṭūsī, theologians used the term mahsusus did not mean that the structure and its essential parts could be sensed or perceived. On the contrary, their intention in using this term was to express that sensation and perception become possible through structure. ${ }^{25}$ Consequently, Rāzì and some Mu'tazilì scholars

22 Rukn al-Dīn Maḥmūd ibn Muḥammad al-Khuwārazmī Ibn al-Malāḥimī, Tuḥfat al-mutakallimīn fĩ al-radd 'alā al-falāsifa, eds. Hasan Anșārī and Wilfred Madelung (Tihrān: Mu'assasah-'i Pizhūhishī-i Hikmat va Falsafah-'i Īrān, 2008), 155, 166ff, 175ff; Rukn al-Dīn Maḥmūd ibn Muhammad al-Khuwārazmī Ibn al-Malāḥimī, Kitāb al-Fā 'iq fi ușūl al-dīn, eds. Wilfred Madelung and Martin McDermott (Tihrān: Mu'assasah-'i Pizhūhishī-i Ḥikmat va Falsafah-'i İrān, 2007), 225ff; Wilfred Madelung, "Ibn alMalāhimìi on the Human Soul," The Muslim World 102, no. 3-4 (October 2012): 431.

Taqī al-Dīn al-Najrānī, al-Kāmil fì al-istiqșā' fìmā balaghanā min kalām al-qudamā’, ed. al-Sayyid alMaḥmūd al-Shāhid (Cairo: al-Majlis al-A 'lā li-al-Shuūn al-Islāmiyya, 1999), 427, 431.

24 Nașīr al-Dīn al-Ṭūīi, Talkhịṣ al-Muḥașșal (Beirut: Dār al-Aḍwā', 1985), 379.

25 al-Ṭūsī, Talkhīṣ 379. 
understood the term al-bunya al-mahsūs in the meaning of "the sensible structure," while Ṭūsī and the later Mu'tazili scholars understood the term as "the perceiving structure." In the first condition, the structure is an object sensed by sense organs while in the second condition it is a subject who perceives via the sense organs.

Because the human soul being beyond the sensible body is held to be self-evident, Taftāzānī would be faced with the following question in the case of interpreting the structure view attributed to the many al-mutakallimūn as the sensible body/ structure: If the soul being beyond the sensible body is self-evident, how could many mutakallimūn adopt a view where the soul is a sensible body or structure in contradiction to self-evidence? This was no question for Rāzì because he did not defend the soul being intrinsic to the body (beyond the body in Taftāzānī's statement) to be self-evident. Taftāzānī overcame the question by following Ṭūsīs interpretation regarding al-bunya al-maḥsūs. Taftāzānī interpreted the term as the perceiving structure. He also stated al-mutakallimūn as the exponents of this view to mean "the essential parts." 26 Thus, according to Taftāzānī, the exponents of the structure view did not argue the soul to be identical to the body, which was in contradiction to self-evidentiality.

\subsubsection{The View of Essential Parts}

The other significant view is the soul as the essential parts. In Rāzì's classification, the view of essential parts is listed under the view where the soul is intrinsic to the sensible body. The essential parts describe the parts of a human that are maintained from the beginning to the end of life. ${ }^{27}$ Stating the scholarly verifiers (al-muhaqqiqūn) as having adopted this view, Rāzì highlighted that many doubts asserted by the deniers of bodily resurrection are removed through essential parts. ${ }^{28}$

According to Taftāzānì, this view is accepted by many to be the same as the view of structure, which was explained above. In other words, he stated its proponents' use of the structure to mean the essential parts rather than the sensible body itself. ${ }^{29}$ 


\subsubsection{The View of the Subtle Body}

I am going to divide the views of the subtle body into three kinds based on their differences with each other: (a) the subtle body that emerges in the heart/brain; (b) the subtle body that is differentiated from other bodies in terms of essence, and (c) the subtle body being the same as other bodies in terms of essence.

The first kind is that the soul is a subtle body emerging in the heart or brain. I numbered this view in Rāzî̀s classification with (i.ii.iv) and in Taftāzānī's with (9). According to proponents of this view, the human soul is a subtle body that appears in the heart and spreads to the organs through the veins. Or the subtle body forms in the brain and penetrates the nerves in it, and then circulates around the whole body. As such, this view has two kinds of expressions depending on whether the soul's source is the heart or the brain. ${ }^{30}$ According to Taftāzānī, the mutakallimūn sometimes called this subtle body the animal soul (al-rūh al-haywānī) and other times the heart soul (al-rūh al-qalbī). ${ }^{31}$ In other words, although some thinkers accepted this subtle body as the essence of the human soul, the mutakallimūn considered it to be the animal soul in man instead of the human soul.

The second kind is the subtle body differentiates from the other body in terms of essence. When ascribing the view of the subtle body to the mutakallimūn, what is usually meant is the view on the essence of the human soul. Rāzi listed this view under that of the soul being the body (al-jism). According to Rāzī, this view assumes the soul to be the luminous, sublime, and subtle body. The soul penetrates the sensible body as rosewater permeates the rose, fire the piece of coal, and oil the sesame seed. Although the human body changes throughout life and decays after death, the soul continues to live without changing or decaying because it has a different essence than other bodies. ${ }^{32}$ This kind is the subtle body view attributed to Mu'tazilī scholars such as Ibrāhīm al-Nazzāām (d. 231/845) and Abū 'Uthmān 'Amr ibn Baḥr al-Jāḥiz (d. 255/868). ${ }^{33}$ According to Taftāzānī, the majority (jumhūr) of al-mutakallimūn defended this view. ${ }^{34}$

According to the third kind, the subtle body is the same as other bodies in terms of essence. The second kind of view of the subtle body is based on a specific physics theory, in which objects need to be accepted as being able to have different 
essences. If someone argues bodies to be the same, accepting the second kind of the subtle body will become impossible for them. Another physics theory proposes all bodies to be homogeneous (mutamäthil); namely, they have the same essence. The third kind coincides with the physics theory that assumes homogeneity of all bodies. This kind of the subtle body view argues the human soul to be a subtle body and the same as all bodies in terms of essence. According to this view, a body does not need to be accepted as different from other bodies in order to explain how the soul can remain unchanged throughout life and survive after death despite the body continuously undergoing change and decaying. This is because God, who is The Acting and Willfully Choosing (al-Fà 'il al-Mukhtär), has power to make the human soul different from other bodies by creating accidents such as combination (ijtima $\bar{a}^{\prime}$ ), life, and persisting ( $\left.b a q \bar{a}^{\prime}\right)$ even though they share the same reality. In this case, a differentiation exists between the human soul and other bodies in terms of accidents, not essence.

Taftāzāni, who included the first two kinds of view of subtle body in Sharh al-Maqāșid, gave no information about this third kinds. In his brief kalāmic works Maquașid and Tahdhīb al-manțiq wa-l-kalām, Taftāzānī mentions three "reliable" views on the essence of the soul: the subtle body, the essential parts, and the immaterial substance. He does not refer to any other view but these. According to him, while the mutakallimūn had adopted the views on the essential parts and the subtle body, the view on the abstract soul had only been argued by some mutakallimūn and philosophers. In these two works that are distinct from Sharh al-Maqāsid, Taftāzānī omits the qualification of differentiating from other bodies. Thereby, he uses the subtle body as a term to be included in the last two kinds of the view of subtle body (i.e., the subtle body being different from other bodies in terms of essence and the subtle body being the same as other bodies in terms of essence).$^{35}$ Furthermore, Taftāzānī stated that, if someone defends both human souls as bodies and all bodies as being homogeneous, then they must accept human souls as being similar to animal souls and their differences to result from their distinction in terms of accidents, not essence. ${ }^{36}$ As I explained at the beginning of this chapter, the mutakallimun do not view the first kind of the subtle body as the essence of the human soul but rather as the animal soul. 
As a result, I put forth that Taftāzānī considered the subtle body view advocated by the mutakallimūn to be two kinds: the subtle body as different from other bodies in terms of essence and the subtle body as being the same as other bodies in terms of essence. I claim that he has adopted the last kind of view of the subtle body and will clarify this claim in detail in Chapter 3.

\subsection{The View of the Immaterial Soul}

Naturalist philosophers generally held material views on the essence of the human soul, such as the sensible body itself, humoral temperament, blood, and the four humors. However, considering the schools of Islamic philosophy, the dominant understanding of the human soul is the view of the immaterial substance. Most Islamic philosophers put forward the division of existents (taqsīm al-mawjūdāt) that include immaterial substances, as they accepted the human soul as the immaterial. ${ }^{37}$

Al-Rāzī stated most metaphysician philosophers, Abū Sahl al-Nawbakhtī (d. 311/924), al-Shaykh al-Mufīd (d. 413/1022), Mu'ammar b. 'Abbād (d. 215/830), al-Ghazālī, and a group of scholarly verifiers among the Sufis to have adopted the view of the immaterial soul. ${ }^{38}$ Taftāzānī ascribed this view to Abu'l-Qāsem al-Ka'bī al-Balkhī (d. 319/931); Abū 'Abdallāh Ḥalīmī (d. 403/1012); Rāghib al-Iṣfahānī (d. 502/1108); Abū Zayd al-Dabūsī (d. 430/1039); al-Ghazālī; the majority of Sufis, Shī a, and Karrāmiyya; as well as to the philosophers. ${ }^{39}$ According to Taftāzānī, this was a reliable view that philosophers and some mutakallimūn defended. ${ }^{40}$

Avicenna, Ilāhiyyāt, ed. Ekrem Demirli and Ömer Türker, 2nd ed. (İstanbul: Litera Publications, 2013), I, 56; Shihāb al-Dīn al-Suhrawardī, "Hikmat al-Ishrāq," in Majmū 'a-yi mușannafät-i Shaykh-i Ishrāq, vol. II (Tihrān: Pizhūhishgāh-i 'Ulūm-i Insānī wa-Muțāla āt-i Farhangī, 1993), 61ff. The origin of the views of Islamic philosophers on the human soul goes back to Aristotle and Plato. Philosophers such as Fārābī and Ibn Sīnā generally adopted the definition of Aristotle, but they considered the soul as an immaterial substance like Plato. See Türker, "Nefis," 529; Atilla Arkan, "Psikoloji: Nefis ve Akıl," in İslâm Felsefesi: Tarih ve Problemler, ed. M. Cüneyt Kaya (İstanbul: İSAM Publications, 2013), 574ff.

al-Rāzī, al-Mațālib, VII, 38; Fakhr al-Dīn Abū 'Abd Allāh Muhammad Ibn 'Umar al-Rāzī, Nihāyat al-uqūl fí dirāyāt al-ușūl, ed. Saīd 'Abd Allāh Fūda (Beirut: Dār al-Zakhāir, 2015), IV, 143ff; al-Rāzī, al-Arba'īn, II, 27.

39 al-Taftāzānī, Sharḥ al-Maqāṣid, II, 211. In Sharḥ al-Maqāṣid, Taftāzānī stated this view to have been adopted by the scholarly verifiers philosophers and the people of Islām. The fact that he attributes this view to "the scholarly verifiers philosophers" does not imply that he also adopted and glorified it, as he saw himself as a theologian, not as a philosopher. On the other hand, Taftāzānī used "said" (qīla) while mentioning each view of the corporeal soul. Because there are ten different views on the corporeal soul while only one view of the immaterial soul. The usage of this word certainly does not mean that he rejected the views of "subtle body" and "essential parts" that he ascribed to the majority of the theologians because, as mentioned in various sections, he clearly stated these two views (i.e., subtle body and essential parts) to be among theologians` reliable views. See al-Taftāzānī, Sharḥ al-Maqāṣid, II, 30; al-Taftāzānī, "al-Maqāṣid," II, 29; al-Taftāzānī, Tahdhīb, 71. 
The dominant view on the essence of the soul in the kalāmic thought from the period of al-mutaqaddimūn was the corporeal soul. Al-mutaqaddimūn strongly objected to the immaterial beings except God because accepting their existence means some entities exist similar to God in terms of certain attributes such as being uninfluenced and needing no agent. These mutakallimūn appear to have wanted to avoid the risk of viewing immaterial beings as being the same as God. To them, the immateriality of a being makes it independent of the agent.

On the other hand, they had no category of being for originated things (muhdathät) apart from the space-occupying substance (mutahayyiz; i.e., the body and the atom) and the thing that is subsisted in it (i.e., the accident). The nonexistence of evidence entails the negation of the thing indicated (kawnu 'adami dalì yastalzimu nafy madlūlih/mā lä dalīla lah yajib nafyuh). This principle states immaterial beings must be refused as no evidence exists for them. ${ }^{41}$ According to Āmidī, the Mu'tazila and most Ash'arites (kathīr min aṣhābinā) negated immaterial beings based on this principle. ${ }^{42}$ After mentioning the four arguments asserted for refusing the soul`s immateriality, Taftāzāni expressed how the opponents of the immaterial soul had propounded a fifth argument based on their principle for rejecting this view. However, Taftāzānī stated the principle of the basis of this argument to be weak because, based on the same principle, someone can dispute it by saying the soul's corporeality also must be refused as no proof exists for its corporeality. ${ }^{43}$

In the period of al-muta'akhkhirūn, some developments set the groundwork for the view of immaterial soul to be common, despite the majority of al-mutaqaddimūn not approving of it. The first development involves abandoning the principle that "the non-existence of evidence entails the negation of the thing indicated," which some of al-mutaqaddimun had previously defended. ${ }^{44}$ The second development is the revision of the method "Similarity in the attributes requires similarity in the person" as "Only the cataphatic (thubütī) attributes of beings, not their apophatic afkār fì ușūl al-dīn, ed. Aḥmad Muhammad al-Mahdī (Cairo: Dār al-Kutub wa al-Wathāik al-Qawmiyya, 2004), III, 28; al-Taftāzānī, Sharḥ al-Maqāṣid, II, 31.

42 al-Āmidī, Abkär al-afkār, III, 28.

43 al-Taftāzānī, Sharh al-Maqãsịid, II, 31. Jurjānī also stated some theologians to have used this weak method, but he does not specify who they were. See al-Sayyid al-Sharif al-Jurjānī, Sharh al-Mawãqif fì 'ilm al-kaläm, ed. Ömer Türker (İstanbul: Türkiye Yazma Eserler Kurumu Başkanlığı Publications, 2015), I, 404. 
(salbī) attributes, necessitate being the same." For instance, Rāzì stated that abstractness of the possible existent does not cause it to resemble the Necessary Existent in the self. ${ }^{45}$ The third development is transference philosophical concepts into kalām. For example, by including the idea of the possibility (imkān) into kalām, the mutakallimūn had the opportunity to accept an immaterial substance as a possible being in itself and this possibility to not annihilate its need for an agent. ${ }^{46}$ Thereby, the criticisms against the view of the immaterial soul lost their bases mainly during the period of al-muta'akhkhirūn. Additionally, some of almutakallimūn at that time considered this view to enable the foundation of some basic principles of belief, such as in the afterlife. It provided the opportunity to explain the afterlife in a way that its deniers could not criticize. ${ }^{47}$

Some contemporary researchers claimed Rāzì to have also adopted the view of the immaterial soul in the context of his certain work. ${ }^{48}$ Examining Rāzī`s view in detail based on his main works, Altaş stated this claim of Rāzì having adopted the view of the immaterial soul to cause problems in consistently explaining his thoughts on theology, physics, metaphysics, and epistemology. He also concluded Rāzì to have not explicitly acknowledged this view at any time in his life. Therefore, according to Altaş, saying that al-Rāzì had approved the concept of the subtle body seems more reasonable when considering his main works. ${ }^{49}$

Making a decisive judgment about the human soul's view of prominent Ash 'arī al-muta'akhkhirūn scholars such as Sayf al-Dīn al-Āmidī (d. 631/1233) ${ }^{50}$, Qāḍī al-

al-Rāzī, al-Mațālib, VII, 26; Altaş, "Fahreddîn Er-Râzîye Göre İnsanın Mahiyeti ve Hakikati -Mücerred Nefs Görüşünün Eleştirisi-," 167ff.

46 Ömer Türker, "Kelam ve Felsefe Geleneklerinin Kesişim Noktasında Seyyid Şerif Cürcânî," in İslâm Düşüncesinde Süreklilik ve Değişim: Seyyid Şerif Cürcânî Örneği, ed. M. Cüneyt Kaya (İstanbul: Klasik Publications, 2015), 14ff.

47 al-Rāzī, Nihāya al-'uqūl, IV, 145; al-Taftāzānī, Sharḥ al-Maqāṣid, II, 211. Taftāzānī also accepted the immaterial substance to be a strong theory in explaining the possibility of the afterlife. See alTaftāzānī, Sharḥ al-Maqāṣid, II, 214.

48 İskenderoğlu, "Fakhr al-Din al-Razi on the Immateriality of the Human Soul," 121-36. For a study asserting that the view of the immaterial soul is defended by Rāzī in his Mabāhith, see Muhammad Fariduddin Attar, "Fahr al-Dīn al-Rāzī on the Human Soul: A Study of the Psychology Section of al-Mabāḥit al-Mašriqiyya fī 'ilm al-Ilāhiyyāt wa-l-Ṭabī iyyāt” (Master`s Thesis, Montreal, McGill University Institute of Islamic Studies, 2014), 53-83.

49 Altaş, "Fahreddîn Er-Râzîye Göre İnsanın Mahiyeti ve Hakikati -Mücerred Nefs Görüşünün Eleştirisi-," 139-95.

50 Attributing the view of the immaterial to a group of Greek philosophers, Islamic philosophers and the proponents of transmigration, Âmidī also cited its fifteen arguments without criticizing or objecting to them. In all of these arguments Āmidi cited, this view was defended by showing the problems that would arise by accepting the corporeality of the soul. In other words, we can see them as arguments for a negation of the soul's corporeality. If he had defended the view of the corporeal soul, he would have at least been expected to respond to and criticize these arguments.. See al-Āmidì, Abkār al-Afkār, IV, 276-81. 
Bayḍāwī (d. 685/1286)51, Shams al-Dīn al-Iṣfahānī (d. 749/1348)52, 'Aḍud al-Dīn al-İjī (d. 756/1355) ${ }^{53}$ al-Sayyid al-Sharîf al-Jurjānī (d. 816/1413) ${ }^{54}$ is difficult. However, their method for studying the subject and their division of existents imply that they had adopted the view of the immaterial soul. Clarifying their views based on their thought systems would be more accurate.

So far, I have examined how Taftāzānī dealt with the issue of the essence of the soul in the chapters from his works related to the soul. As was shown, he reinterpreted the views on the essence of the soul that had been asserted before him. Yet he did not clearly express which view he accepted. According to him, the views on the immaterial soul, the subtle body (having the different essence or having the same essence), and the essential parts are reliable, with no proof found able to demonstrate one or the other being true or false for certain.

Taftāzānī also analyzed the primary arguments that form the basis of the two main views on the issue (i.e., the view of the corporeal soul the and the view of the immaterial soul). He mentioned the five arguments that had been put forward by followers of the view of the corporeal soul. He considered four arguments to have been propounded based on the assumption that the immaterial soul cannot

51 In this context, for example, Bayḍawi states the reason and point revealing the idea of the abstractness of the soul, then lists rational (aqlī) and revealed (naqlī) arguments. After mentioning rational arguments, he called only the one "weak." Presenting the verses, contrary to his previous statement, Baydawi expressed that they indicate the soul's difference from the sensible body instead of its abstractness. After explaining the view of the abstractness soul in detail, he listed views on the souls`corporeality, neither mentioning their arguments nor making any evaluations about them. See Qādị Nașīr al-Dīn Abū 'Abd Allāh b. 'Umar Bayḍawī, Ṭawāli ' al-anwār min mațāli ' al-anzāar, ed. 'Abbās Sulaymān (Beirut and Cairo: Dār al-Jīl and al-Maktabah al-Azharīyah lil-Turāth, 1991), 150ff. Bayḍawī`s contemporary Shi'î-Imāmī theologian Ṭūsī openly defended the abstracted soul. See Nașīr al-Dīn al-Ṭūsī, Tajrīd al'aqāid, Ed. 'Abbās Muḥammad Ḥasan Sulaimān (al-Iskandariya: Dār al-Ma ārif al-Cāmi iyya, 1996), $95 \mathrm{ff}$.

52 Shams al-Dīn Abū al-Thanā' Maḥmūd ibn 'Abd al-Raḥman ibn Aḥmad al-Iṣfahānī, Tasdīd al-qawā 'id fì sharh Tajrīd al-'aqā'id, ed. Khālid b. Hammād al- 'Adwānī (Kuwait: Dār al-Ḍiyā', 2012), I, 679-89.

53 After mentioning the immaterial soul, İjī gives place to its arguments and objections to them. Later, he moves to the view of the soul's corporeality and lists the sub-views put forward in this framework. However, he does not mention any arguments for these corporeal soul views and clearly states none of these views to be reliable. See 'Aḍud al-Dīn al-Ījīi, al-Mawāqiffí 'ilm al-kalām (Beirut: 'Ālam al-Kutub, n.d.), 260. Türker stated $\overline{\mathrm{I} j} \mathrm{i}$ to have adopted the immaterial soul view considering his statement that "none of the views mentioned by defenders of the corporeal soul is reliable." See Ömer Türker, "Kelâm Geleneğinde Adudüddin El-Î́cî: Kelâmın Bilimsel Kimliği Sorunu," in İslâm İlim ve Düşünce Geleneğinde Adudüddin El-Î́î (İstanbul: İSAM Publications, 2017), 303.

54 Contemporary researchers generally argue that Jurjānī also agreed with the philosophers on the abstractness of the soul. See Türker, "Kelam ve Felsefe Geleneklerinin Kesişim Noktasında Seyyid Şerif Cürcânî," 17. 
have a direct relationship and connection with the particulars. ${ }^{55}$ He criticized these arguments within that framework. I will introduce only the first argument as an example: When the soul makes a judgment, it must perceive both terms of the judgment. The soul must perceive both the corporeal particular (this fire) and the universal (hot) to make a judgment such as "this fire is hot." By being able to perceive the corporeal particular, the soul has to be a material substance. According to Taftāzānì, someone who advocates the view of the immaterial soul can oppose this argument by saying that the soul is the knower and perceiver of both the particular and universal knowns. Therefore, these arguments prove to him that the immaterial soul cannot directly relate with particulars and corporeal beings apart from the view that the soul is the immaterial substance. ${ }^{56}$ Finally, Taftāzānī's approach toward the immateriality of the soul in itself is distinct from the abstraction/negation of the direct relationship of the soul with corporeal particulars.

The impossibility of the soul being immaterial differs from the impossibility that the soul has a direct relationship with the corporeal being. Islamic philosophers put forth the emanation theory to explain the relationship the First Principle, which is far removed from any kind of multiplicity or materiality, has with material beings, which do have multiplicity. They next transferred the emanation theory to epistemology and argued the immaterial and abstracted soul to be unable to directly perceive the particulars. For the philosophers, the immateriality of the soul necessitates not being directly related to the corporeal particulars. Therefore, the philosophers needed external and internal sense faculties to explain how the immaterial soul perceives material particulars. In this way, although the immaterial soul perceives the universals directly, it can perceive the particulars only through the external and internal sense faculties. When the soul leaves the body at the time of death, it is no longer to perceive the particulars. ${ }^{57}$

While mentioning these arguments, Taftāzānīs expression "our arguments are these" implies that he also adopted the view of the corporeal soul. See al-Taftāzānī, Sharḥ al-Maqāṣid, II, 29ff; al-Taftāzānī, Tahdhīb, 71.

56 al-Taftāzānī, Sharḥ al-Maqāṣid, II, 30ff. Rāzī also pointed out that the main arguments attributed to the supporters of the corporeal soul negate the abstraction of the soul from the corporeal particulars during the perception process instead of the soul`s abstractness in itself. See Murat Kaş, "Seyyid Şerîf Cürcânî'de Zihnî Varlık” (PhD Dissertation, İstanbul, Marmara University Social Sciences Institute, 2017), 103-5.

57 Kaş, “Seyyid Şerîf Cürcânî̀de Zihnî Varlık”, 103. 
During the time of al-muta'akhkhirūn, the Ash 'arī theologians who'd adopted the view of the immaterial soul or at least considered it as something possible, evidently opposed and rejected the view of Islamic philosophers where the immaterial soul is unable to perceive particulars directly. It was because, according to al-mutakallimūn, this view entails unacceptable results in terms of the main goals (maqāṣid) of kalām. For example, al-Ghazālī, unlike other philosophers, considered the soul not to be abstracted from the material and corporeal processes, even though he accepted the soul as being immaterial in itself. He firmly opposed the constitution of a hierarchy between the soul and corporeal beings. ${ }^{58}$ By arguing knowledge to be a relation, Rāzī also found the opportunity to explain that God directly knows the particulars and that the immaterial soul can perceive the corporeal particulars without any corporeal organs or senses. ${ }^{59}$ According to Rāzī, the soul perceives both universals and particulars, and the first argument also indicates this reality. ${ }^{60}$

Accepting the external and internal sense faculties, Taftāzānī mentioned these faculties to only have the instrumental function in perceiving the corporeal particulars. Moreover, unlike other philosophers, he considered these faculties to be unnecessary for perceiving the corporeal particulars and the soul to be able to perceive all particulars without any faculty whatsoever. In other words, even if human beings have no sense faculties, God has the power to allow the soul to have perceptions about the corporeal particulars. According to Taftāzānī, the claim that the soul is unable to directly perceive the corporeal particulars is in accordance with neither reason nor the divine texts (nașș). However, the views of the immaterial soul in itself or the corporeal soul do not contradict them. Therefore, while no religious or intellectual problem exists in accepting the immaterial soul, considering perceiving the corporeal particulars directly as impossible and arguing the sense faculties to be necessary for perceiving the particulars are unacceptable because the

58 Kaş, “Seyyid Şerîf Cürcânî̀de Zihnî Varlık”, 81-84.

59 Kaş, "Seyyid Şerîf Cürcânîde Zihnî Varlık”, 101-5. For a comparative study dealing with problems on the abstracted soul in terms of the knowledge of particulars and how these problems were tried to be solved in the later period, see Ziya Erdinç, "Klasik Sonrası İslâm Düşüncesinde İnsanın Hakikatine İlişkin Önemli Bir Sorun: Soyut Nefis Tikelleri Bilebilir Mi?,” in The Construction of Human, Creed and Space-II: Values and Concepts International and Inter-Disciplinary Symposium on Soul (Çanakkale: ÇOMÜ Publications, 2021), 429-46.

60 Kaş, "Seyyid Şerîf Cürcânî'de Zihnî Varlık”, 101-5; al-Rāzī, Muhașṣal, 229; Fakhr al-Dīn Abū 'Abd Allāh Muḥammad Ibn 'Umar al-Rāzī, al-Mabāhith al-mashriqiyya fì ‘ilm al-ilāhiyyāt wa al-tabī'iyyāt, ed. M. Mu'tașim-Billāh al-Baghdādī (Beirut: Dār al-Kitāb al-'Arabī, 1990), I, 450; II, 345, 359. 
divine texts definitively show the human soul to continue to perceive the corporeal particulars and the sense faculties after leaving the body at the time of death. ${ }^{61}$ According to Taftāzānī, the sense faculties have no effect over any knowledge of human beings; instead, knowledge comes into existence through God's creation. God is the only effective cause of knowledge. The soul is the apparent cause and real perceiver of all knowledge, and the senses are exclusively instruments. ${ }^{62}$

After discussing the arguments regarding the corporeality of the soul, Taftāzāni started to study the arguments the proponents of the view of the immaterial soul had put forth. They propounded these arguments generally by referencing that certain perceptions of the soul would not occur if it were a corporeal substance. According to Taftāzānī, all arguments are based on the theory of specific perception. That is why these arguments cannot be directed toward those who have not adopted the perception theory. In other words, these arguments are weak by reason of the philosophers' presuppositions being based in relation to the immaterial soul and its perception. ${ }^{63}$

Consequently, despite evaluating the arguments given by supporters of both main views to be weak, Taftāzānī presented no new proof that would be trustworthy for any of the views. Contrary to al-mutaqaddimūn, who'd firmly rejected the existence of immaterial being apart from God, he thought no evidence existed showing either the necessity or impossibility of immaterial beings. Therefore, the view of the soul as being immaterial can neither be proven nor denied based on a definitive proof. ${ }^{64}$

Although Taftāzānī considered three main views regarding the soul's essence to be reliable and possible, does any view exist that he adopted? Seeing different views as possible theories does not mean he admitted concurrently all of them as the soul's essence. I am going to reveal the view that Taftāzāni adopted by determining his opinions on the various issues that had affected his approach to the soul's essence. For example, in the chapter where he examines the theories of the body, although he states the arguments of both hylomorphism and atomism to

62 Sa 'd al-Dīn Mas' ūd b. 'Umar b. 'Abd Allāh al-Taftāzānī, Sharḥ al-'Aqāid al-Nasafiyya, ed. Aḥmad Hijāzī al-Sakkā (Cairo: Maktabat al-Kulliyyāt al-Azhariyya, 1988), 15.

63 al-Taftāzānī, Sharḥ al-Maqāṣid, II, 31-35.

64 al-Taftāzānī, Sharḥ al-'Aqãid, 27. 
be weak, he emphasizes hylomorphism to have some unacceptable consequences in matters of Islamic beliefs. ${ }^{65}$ Thus, he aimed to express that he does not adopt hylomorphism because of such results. However, unlike hylomorphism, the view of immaterial soul does not endanger Islamic belief.

\section{Taftāzānīs View on the Essence of the Soul}

In this section, I will summarize how Taftāzānī conceived of man by considering on one hand his statements directly related to the human soul as presented in the previous sections. On the other hand, I will pay attention to his explanations on main subjects such as epistemology, physics, metaphysics, and theology in detail in the next chapter in an attempt to show how I determined his conception of man outlined here based on his system of thought.

Taftāzānī often reinterpreted the inherited tradition to lay the groundwork for and justify his thought. For instance, I stated that he had opposed the interpretation of the structure view as the sensible body in order to reveal his view on the human soul. Thus, he completely rejected the extreme corporeal view of the soul that reduces it to the sensible body. By considering the soul's existence beyond the sensible body as an obvious principle, he in a sense approaches the view of the immaterial soul. However, he argues on the other hand that both the soul and the sensible body are corporeal in order to avoid a duality between them. Then to build his concept of man, he goes on to benefit from the two views (the subtle body and essential parts) that al-mutakallimūn had adopted and which he saw within the framework of the soul's existence beyond the sensible body. Accepting that the essence of the human soul consists of only the subtle body, Taftāzānī used the view of the essential parts to ground the essence of the sensible body. Accordingly, I will summarize his conception of man within the framework of the following four elements based on his system of thought:

(i) The human soul is a subtle body that is homogenous with other bodies; namely, it is the same as them in terms of essence. This subtle body comprises the human itself and constitutes its essence. In other words, the human soul alone as a subtle body is what makes a human human. While some of al-mutakallimūn argued this subtle body to be different from other bodies in terms of essence, Taftāzānī accepted this subtle body as having the same essence as other bodies. 
When introducing the arguments for the view of a corporeal soul, Taftāzāni attributed them to al-mutakallimūn, of whom he was one, by using the sentence of "These are our arguments." This implies that he adopted this view. ${ }^{66}$ However, after examining the arguments of al-mutakkalimūn and the philosophers, he stated both sides' arguments to be weak and made no mention of any extra argument. ${ }^{67}$ Given the discussing language of al-muta'akhkhirūn scholars, Taftāzānī's statement in which he includes himself among the proponents of the view of the corporeal soul is not enough by itself to prove that he had adopted this view. Therefore, by taking into account his views on various issues, I have concluded in this study that he had adopted the view of the subtle body having the same essence. It is because the other subjects where he did explicitly state his thoughts reveal his definitive view on the essence of soul, despite him not clearly stating that to be "the correct and strong view."

(ii) The essential parts. The parts of the sensible body are divided into two parts: the essential and the superfluous. The essential parts of the sensible body constitute the essence of the sensible body apart from the human soul. These parts remain with the human body from the beginning to the end of its life, and as such will provide the basis for the bodily resurrection in the afterlife.

(iii) The superfluous parts. These are the parts that exist in a human's sensible body at certain period of life. The bodily resurrection does not require all these parts to return exactly as they were; on the contrary, only a similarity will be returned to the human body.

(iv) The animal soul. The vapor-like animal soul is also a subtle body and establishes the link between the densely-compacted body and the subtle human soul.

\section{The Essence of Human Soul in al-Taftāzānīs Thought}

I derived the four elements from Taftāzānīs evident views on epistemology, physics, ontology, and theology. As stated before, he considered and highlighted the immaterial soul, the essential parts, and the subtle body to be reliable views on the essence of the human soul. I do not claim here that all of his thoughts related to the main subjects are incompatible with the views of the immaterial soul and the essential parts while examining his thought system in regard to the conception 
of the soul because his views on some subjects coincide with the immaterial soul, while his views on other subjects are incompatible with the essential parts. In this context and based on Taftāzānī's thoughts about physics and the essence of angels, I have concluded that he was unable to acknowledge the essential parts of the human soul. Similarly, By taking into account his thoughts about the life in the grave and the resurrection, I have concluded that he could not have accepted the human soul to be the essential parts.

Meanwhile, I have focused on his thoughts on ontology and epistemology to show how he had rejected or reinterpreted some propositions generally accepted by the ancient Ash 'arīs in order to resolve the problems of the subtle body view. I think his approach in ontology and epistemology had arisen from his seeing the essence of the human soul as a subtle body. Therefore, I will try to show the only view that is fully compatible with his opinions on all relevant subjects in his thought to be that of the subtle body having the same essence as other bodies.

\subsection{The Concept of Physics}

Islamic thinkers formed their division of existents in accordance with concept of existence. They revealed their division in a way that would involve all existents and not exclude anyone. The scholars` divisions of existents also provide crucial information about their views on the essence of the human soul.

The divisions of existents as put forward by the Peripatetic (Mashshāī) and Illuminationist (Ishrāqī) philosophers involve a category that includes immaterial being apart from God. Dividing the existents into two main parts as necessary and possible beings, the Peripatetic philosophers called the being that is subsisted in a subject without being a part of the subject as an accident, and the being that exists without inhering in a subject as substance. Substances are also divided into five categories: body (jism), matter ( $m \bar{a} d d a)$, form (șüra), intellect ('aql), and soul (nafs). Of these, body, matter, and form are corporeal while intellect and soul are immaterial substances. Although the soul has a relationship of management and control with objects, the intellect is a substance removed from objects in every aspect. ${ }^{68}$ According to the Illuminationists, being is divided into two parts: state (al-hay'a) and substance. Space-occupying being is called bodily (jirmānī), and being that does not occupy space is called spiritual (rūhānī). Accordingly, while the body 
is included in the category of bodily substances, the soul and intellect are in the category of spiritual substances. Therefore, human souls are included in the class of immaterial and incorporeal substances in both schools` divisions. ${ }^{69}$

Because al-mutaqaddimūn had a general concept of the corporeal soul and considered the existence of immaterial beings apart from Allah to be impossible, they did not include a category of immaterial beings in their division of existents. According to them, two kinds of beings exist: the eternal (qadim) and the temporally created (hädith). Temporally created beings have substance (the space-occupying/ al-mutahayyiz) and accident (subsisted upon the space-occupying). Divisible substances are called bodies, and indivisible substances are called atoms (al-jawhar al-fard). When the view of immaterial beings became widespread in theological thought after al-Ghazali, some changes occurred in the division of existents. For instance, a third category is seen to have been included for the temporally created being that is "neither space-occupying nor subsisted in the space-occupying." Despite mentioning this third category in their divisions, some theologians tried to reveal the impossibility of this category of beings. ${ }^{70}$

Taftāzānī's division also has two kinds of temporally created beings: the substance that directly occupies space and the accident that indirectly occupies space. If the substance is divisible, it is the body; if it is not, it is the atom. ${ }^{71}$ The division in Tahdhīb, Taftāzānī's last work on theology and logic, has no category for immaterial beings apart from God. If Taftāzānī accepted the human soul as an abstracted being, he would be expected to have provided a category involving the immaterial being as his attempt was to try and form division classifying every kind of being. In the division he attributed to al-mutakallimūn in his Sharh al-Maqāșid, he mentioned a third category as "neither the space-occupying nor subsisted in the space-occupying," in which he included immaterial beings. However, he stated in relation to this that immaterially created substances do not have a specific existence due to the weakness of evidence. Therefore, al-mutakallimūn did not consider immaterial being as a category of created beings. ${ }^{72}$

The division Taftāzānī adopted shows that he accepted atomism over the hylomorphic theory. He pointed out the contributions kalām atomism had in

70 Bayḍawī, Ṭawāli ', 76; Qāọī Nașīr al-Dīn Abū 'Abd Allāh b. 'Umar Bayḍawī, Misbāḥ al-arwāḥ fi uṣūl al-dīn, ed. Saīd 'Abd Allāh Fūda ('Ummān: Dār al-Rāzì, 2007), 85.

71 al-Taftāzānī, Tahdhīb, 35ff, 56ff.

72 al-Taftāzānī, Sharḥ al-Maqāṣid, I, $173 \mathrm{ff.}$ 
accepting and defending Islamic principles. ${ }^{73}$ However, different types of atomism exist in kalām thought. We must determine which type of atomism he had accepted to be able to figure out which part of the view of the subtle body he also accepted. Each view of "the subtle body having different essence" and "the subtle body having the same essence" is compatible with a different type of atomism. If the type of atomism he accepted can be determined, revealing which kind of subtle body he defended will also be possible.

When examining the view of the subtle body having a different essence, it is seen this does not coincide with Taftāzānī's concept of physics because the most important characteristic of this view is claim that, despite having a subtle body, the soul is different from other bodies in terms of essence. Taftāzānī persistently rejected bodies as being different in terms of essence. To better understand the issue, touching briefly upon the types of atomism in kalām will be helpful.

Al-mutakallimūn refused to conceptualize the form of species, and explained the world's physical structures based on atoms and accidents. They adopted different types of atomism to clarify the differences and similarities between temporally created beings. The types of atomism of the theologians can be divided into three:

\section{(i) Homogenous (mutamāthil) Bodies Composed of Homogenous}

Atoms. ${ }^{74}$ This type of atomism argues all atoms to have the same essence and bodies composed of atoms to also have the same essence (mutamäthil). ${ }^{75}$ Since all atoms are identical in their essential attributes (al-sıfāt al-nafsī) such as being a substance, being space-occupying, and being the recipient of accidents, they are homogenous in terms of essence. Because the accidents are not included in the essence of the body, the bodies composed of homogenous atoms are naturally the same in terms of essence. Although the accidents entail the bodies to differ from

73 al-Taftāzānī, Sharḥ al- 'Aqāìd, 25; al-Taftāzānī, Tahdhīb, 60.

74 Accepting the homogeneity of the bodies necessarily entails accepting the homogeneity of atoms. Therefore, the term "homogeneous bodies" when used alone also expresses the homogeneity of atoms.

75 Abī Bakr Muhạmmad ibn al-Hasan Ibn Fūrak, Mujarrad maqūlāt al-Shaykh Abì al-Hasan al-Ash 'arī, ed. Daniel Gimaret (Beirut: Dār al-Mashriq, 1987), 265ff; Qāḍī 'Abd al-Jabbār, Sharh al-Ușūl al-khamsa (Cairo: Maktabatu Wahba, 1988), 92, 219ff; 'Abd al-Malik ibn 'Abd Allāh Imām al-Ḥaramayn alJuwaynī, al-Shāmil fĩ uṣūl al-dīn, eds. 'Alī Sāmī Nashshār, Fayṣal Budayr 'Awn, and Suhayr Muhammad Mukhtār (al-Iskandariya: Munsha'āt al-Ma'ārif, 1969), 153ff; 'Abd al-Malik ibn 'Abd Allāh Imām alḤaramayn al-Juwaynī, Kitāb al-Irshād ilá qawāți ' al-adillah fĩ ușūl al-i 'tiqād, ed. Muhạmmad Yūsuf Mūsā (Cairo: Maktaba al-Khanjī, 1950), 38ff; Abū al-Yusr 'Alī ibn Muhammad al-Bazdawī, Ușūl al-dīn (Cairo: al-Maktaba al-Azhariyya li-1-Turāth, 2003), 34ff; al-Āmidī, Abkār al-Afkār, III, 36. 
each other due to being subsisted in them, this differentiation is in regard to the accidents, not the essence. Consequently, as all atoms have the same essence and bodies are composed of atoms, bodies must also be homogenous. ${ }^{76}$

According to Taftāzānī, atoms do not have any essential qualities other than the above-mentioned attributes. Therefore, attributes such as weight and shape that are subsisted within atoms are not essential qualities. Because atoms do not have weight in themselves, a body composed of fewer atoms may be heavier than a body composed of more atoms. If the claim is made that each atom has a certain weight in itself, a body with a greater number of atoms would necessarily be heavier. ${ }^{77}$

Saying that atoms are homogenous, Taftāzānī argued the bodies composed of atoms to also be homogenous in form. According to him, one of the universal judgments (al-ahkām al-kulliya) about objects is that they are homogenous (i.e., they have the same essence). Because they are homogenous, what is possible for one is also possible for the other. Therefore, any difference between them arises from accidents, which are completely based on the power of The Willfully Choosing Creator. ${ }^{78}$ After stating bodies to be the same in terms of essence and the differences to arise from accidents, he manifests that many Islamic principles such as the existence of The Willfully Choosing Almighty as well as several issues related to prophethood and the resurrection to be demonstrable based on this general judgment. ${ }^{79}$ For example, Taftāzānī, who definitively advocated that the ascension of the Prophet ( $m i{ }^{\prime}$ rajj) had occurred with keenness of mind (yaqaza) and his sensible body, explained the possibility of this miracle based on the homogeneity of bodies. According to Taftāzāni, because the sky and Earth are composed of homogenous bodies, man can go through the sky just as he passes through the bodies on Earth. ${ }^{80}$

This judgment is central to the foundation of all miracles. For instance, Peripatetic philosophers argued celestial bodies to be unable to be recipients of generation or al-dìn, 34ff; al-Āmidī, Abkār al-afkār, III, $103 \mathrm{ff}$.

77 al-Taftāzānī, Sharḥ al-Maqāṣid, I, 206, 375.

78 al-Taftāzānī, I, 317ff. Rāzī, who stated the idea of homogenous bodies to be a great view in proving the Islamic principles, also said that only this way can demonstrate God as the Free-Willed Creator, the miracles of the prophets, the resurrection, q1yāma. The homogeneity of bodies is a significant principle because proving the subjects of divinity, prophecy, and the resurrection are based on it. See al-Rāzī, al-Mațālib, VI, $189 \mathrm{ff}$.

79 al-Taftāzānī, Sharḥ al-Maqāṣid, I, 311-12, 318, 328, 337; II, 69, 193; al-Taftāzānī, Sharḥ al-'Aqāid, 91; al-Taftāzānī, Tahdhīb, 60 .

80 al-Taftāzānī, Sharḥ al-Maqāṣid, II, 193. 
corruption. On the contrary, according to Taftāzānī, both celestial and terrestrial bodies are recipients of combination and separation, thus proving the possibility of the miracle of the splitting of the moon. As a result, the logical possibility that God, who is The Willfully Choosing Almighty, created different species just by changing or renewing their accidents without altering the atoms in any of the bodies in the world is also provided by the theory of the homogeneity of bodies.

(ii) Differentiated Bodies Composed of Homogenous Atoms. According to this type as adopted by some atomist theologians, because atoms have the same essence, they are homogenous. However, the bodies composed of atoms are not homogeneous. On the contrary, they are differentiated (mutakhälif) substances in terms of their essence. The way to differentiate in regard to essence is to include the accidents within essence. Thus, because a body's essence is composed of differentiated accidents and homogenous atoms, the essences also are different. ${ }^{81}$ In this context, accidents can become a part of the essence of corporeal species. This sort of accident is not subsisted within the body but within the atoms, which are another part of the body. Therefore, while that kind of accident is essential in respect to the body, it is also accidental in respect to the atoms that are another part of the body. ${ }^{82}$ The followers of this type of atomism tried to solve the problem of how an accident could be a part of a body in which it had inhered, based on the distinction of "part with respect to part" and "part with respect to compound." ${ }^{83}$

This type of atomism coincides with the view of "the subtle body having different essences." Namely, the subtle body as the essence of a human is essentially alive due to the life accident, which is its primary quality. The essence of this subtle body is composed of atoms and the life accident. In other words, because the life accident, as an essential quality of the human soul, is a part of its essence, it becomes differentiated from other bodies in terms of essence. For example, the life accident in the animal and vegetable souls is not included in the essences of these bodies. Therefore, while the human soul is alive in its essence, the other souls are accidentally alive.

81 al-Taftāzānī, Sharḥ al-Maqāṣid, I, 312, 318.

82 al-Taftāzānī, Sharḥ al-Maqāṣid, I, 312, 317; al-Sayyid al-Sharīf al-Jurjānī, Hāshiya 'alā Sharḥ al-Mukhtaṣar al-muntahā al-ușūlì, ed. Muḥammad Ḥasan Ismā ìl (Beirut: Dār al-Kutub al-' Ilmiyya, 2004), I, 243.

83 Alexander of Aphrodisias previously used this distinction to solve the problems about the form`s being substance. See İbrahim Halil Üçer, İbn Sînâ Felsefesinde Suret, Cevher ve Varlık (İstanbul: Klasik Publications, 2017), 140ff. 
(iii) Differentiated Bodies Composed of Differentiated Atoms: Unlike the former two types of atomism, this type does not accept the sameness of atoms in terms of essence. Because atoms have different essences, the bodies composed of atoms must also have different essences. According to those who argue atoms to have different shapes and these shapes to be their essential attributes, they have different essences. For Taftāzānī, the followers of this view based the differences between objects not on accidents but on shapes, which are essential attributes. ${ }^{84}$ While some statements of al- $\overline{\mathrm{I}} \mathrm{j} \overline{1}$ show him to have adopted this type of atomism, ${ }^{85}$ his other statements indicate him to have advocated the first type of atomism. ${ }^{86}$

Taftāzānī, who adopted the view that homogeneous bodies are composed of homogeneous atoms, must have unaccepted the view of the subtle body having different essences, as this is incompatible with his type of atomism. This view of the soul coincides with the other two types of atomism as these types argue bodies to have different essences. In this case, saying that Taftāzānī accepted the view of the subtle body having the same essence would be more reasonable as it is consistent with his type of atomism.

\subsection{Epistemology}

A strong relationship exists between psychology and epistemology. A systematic thinker's views on the essence of the soul should be compatible with their concept of knowledge. Due to the strong connection between epistemology and soul theory, thinkers also revealed the main framework of their epistemology in their works involving the concept of the soul. ${ }^{87}$

In theological and philosophical works, the majority of the arguments put forward by Islamic scholars for proving the immaterial soul are based on epistemology. For instance, when examining these arguments, they are seen to have appeared in the following forms: "The occurrence of the forms of universals in the atomism see Mehmet Bulğen, Kelâm Atomculuğu ve Modern Kozmoloji (Ankara: TDV Publications, 2015), 94ff.

85 al-Ījīi, al-Mawāqiif, 186.

86 al-Ījī, al-Mawāqif, 244, 252, 266.

87 Ömer Mahir Alper, Aklın Hazzı: İbn Kemmûne'de Bilgi Teorisi (İstanbul: Ayışığı Kitapları Publications, 2004), 37; Avicenna, Kitāb al-Nafs, 32-227; Aristotle, Ruh Üzerine, trans. Zeki Özcan (İstanbul: Alfa Publications, 2000), 63-211. 
corporeal soul is impossible because knowledge is the occurrence of the form (hușūl al-șüra)", "the occurrence of the forms of simples in the corporeal soul is impossible because knowledge...." or "the occurrence of the forms of opposites in the corporeal soul is impossible because knowledge is the occurrence of the form...." ${ }^{88}$ Most of the arguments Taftāzānī had ascribed to the exponents of the immaterial soul are directly related to the theory of knowledge. ${ }^{89}$

Knowing the basis for the arguments of the view of the immaterial soul in Avicenna's epistemology to be the idea of the occurrence of the form, Taftāzāni reinterpreted Avicenna's concept of perception (idrāk) to also be consistent with the view of the corporeal soul and then incorporated this into his thought. ${ }^{90}$ Although Taftāzānī accepted the occurrence of a form in the soul while acquiring knowledge, he mentioned the soul to have no need to be immaterial to do this. On the contrary, the forms of knowns can occur in the corporeal soul as well as in the immaterial soul. According to Taftāzānī, if one additionally rejected the occurrence of the form during the acquirement of knowledge and accepted knowledge as consisting only of relation (id̄a $f a$ ), the criticisms of the supporters of the immaterial soul over the corporeal soul would lose their basis. ${ }^{91}$ For instance, Rāzī and Mu'tazilì theologians countered these arguments by accepting knowledge as a relation. However, because Taftāzāni thought this would cause other problems in the system of thought, he did not find relation adequate in the occurrence of knowledge and argued that form should also occur.

\subsection{The Ontology}

If someone accepts the view of the subtle body or the essential parts regarding the human soul, they should be able to solve the most critical problem: Who is qualified with the attributes of knower, living, mighty, obligated, and such? This problem can be detailed as follows: If an atomist mutakallimūn defended the human soul as a corporeal body, they would eventually have to accept this body to be composed

91 al-Taftāzānī, Sharḥ al-Maqāṣid, II, $31 \mathrm{ff.}$ 
of atoms, no matter which kind of corporeal body view they adopted. Because accidents cannot inhere in more than one substratum (mahall), accidents such as knowledge, perception, power, and life will also be subsisted in certain atoms of the soul, not in all the atoms of the soul (i.e., not in the entire soul). In this case, do the whole of the human soul or only the parts in which the attributes are subsisted be qualified as being alive, being mighty, and being obligated? How can a human as a whole be called a "knower" when knowledge is subsisted in a particular organ (i.e., the heart) or only in one or a few atoms in this organ? Again, while attributes such as life, power, and hearing are inhered in limited atoms, why does that which is composed of more atoms (i.e., the human soul) qualify as being alive, knowing, seeing, and acting? ${ }^{92}$ If the essence of man is composed of some atoms in which an accident of knowledge is subsisted and of other atoms in which knowledge does not, a human may be qualified as knower but only in the figurative meaning (al$m a$ 'nā al-majāzì) because the accident of knowledge provides being qualified as knower in the true meaning (al-ma 'nā al-haqiq $\bar{l}$ ) only for the atoms in which it has been subsisted. This can also be applied to other accidents as well.

Arguing man to consist of this sensible body (i.e., composed of many atoms), Abū Hāshim al-Jubbā'ì tried to solve this problem using the theory of states (ahwa $\bar{a} l) .{ }^{93}$ According to him, although the knowledge accident is subsisted only in the atoms located in the heart, it is the cause of a state ( $h \bar{a} l)$ that qualifies the compound as a whole. In other words, despite the knowledge in a human's heart only qualifying the atoms in which the knowledge is subsisted, the state caused by the knowledge accident enables the whole being of the human to be called the knower. Through aḥwāl, a human may be qualified wholly as knower, alive, and mighty not figuratively but truly. ${ }^{94}$ Al-Juwaynī, who accepted the theory of states, draws attention to ahwāl theory for solving this problem. According to him, Ash'arīs, who opposed the theory of states, cannot possibly rationally clarify how they name the whole of a man composed of atoms as "knower" in the true meaning. Contrary to accidents, the ahwāl theory provides the opportunity to use

92 Richard M. Frank, "Abū Hāshim's Theory of «States»: Its Structure and Function," in Actas Do Congressu de Estudios Arabes e Islámicos (Leiden: Brill, 1971), 89ff; Ayman Shihadeh, "Classical Ash'arī Anthropology: Body, Life and Spirit," The Muslim World 102, no. 3-4 (October 2012): 462.

93 Frank, "Abū Hāshim's Theory of «States»: Its Structure and Function," 89ff.

94 Frank, 90, 95ff; Richard M. Frank, Beings and Their Attributes: The Teaching of the Basrian School of the Mu 'tazila in the Classical Period, Studies in Islamic Philosophy and Science (Albany: State University of New York Press, 1978), 38-55; Shihadeh, "Classical Ash'arī Anthropology: Body, Life and Spirit," 433-77. 
the adjective of "knower" for a human in the real sense due to its functions of being subsistent in the whole and qualifying it. ${ }^{95}$

Maintaining the classical Ash 'arī opposition to aḥwāl theory, al-mutakallimūn such as al-Qalānisī (d. $4^{\text {th }} /$ early 10 ${ }^{\text {th }}$ century) and Abūl-Qāsim al-Anșārī (d. 512/1118) also stated that accidents could only be subsisted in certain atoms. They claimed an accident to only be able to enable the atoms in which it has been subsisted to be qualified with attributes such as knower and alive in the true sense. Thus, these scholars argued that the entire sensible body (i.e., the essence of man) is metaphorically qualified with attributes. ${ }^{96}$

In the current study, I claim Taftāzānī to have adopted the view of the subtle body being the same as other bodies in terms of essence with regard to the essence of the human soul. If this claim is true, he must have solved the ontological problem mentioned above. Yes, he attempted to solve the problem by making changes to some of the teachings of al-mutaqaddimūn. First of all, according to Taftāzānī, if the soul is accepted as a subtle body, the agent subjected to knowing and living is not the sensible body but the subtle body spreading to it. All perceptions and other essential attributes of man are subsisted in the subtle body. Meanwhile, the accidents subsisted in the subtle body can inhere in it in terms of being whole. In this sense, according to him, the substratum of knowledge is the heart. What is meant by the heart is not the sensible organ seen during surgery and also existed in animals. On the contrary, he means the heart as in the "human soul, through which humans are distinguished from other beings." ${ }^{97}$

The knowledge accident is subsisted either in (i) the entire subtle body as a whole, (ii) in each of its atoms separately, or (iii) only in some atoms within the body. I've stated accepting the third possibility to mean the soul must be qualified as a knower in a figurative sense. As assumed in the second possibility, if knowledge is subsisted in each atom of the human soul separately, when a single instance of knowledge occured, as much knowledge as the number of atoms constituting the human soul must also exist in the human, because to qualify the human as a whole knower in the true sense, the knowledge accident must exist in its all atoms. That is unacceptable. Despite Taftāzānī’s rejection of aḥwāl, no obstacle is seen in assuming 
the first possibility (i.e., the entire subtle body as a whole) because he interprets almutaqaddimūn's principle "that an accident cannot subsist in multiple substratum" to have a different meaning. According to Taftāzānī, what al-mutaqaddimūn meant by this principle is that a single accident cannot simultaneously be subsisted in one substratum while being inhered in another substratum. Otherwise, they do not mean an accident is unable to be subsisted in something composed (majmū') of many atoms that have been turned into a single substratum for the accident through the combination (ijtima $\bar{a}^{\prime}$ ) that is inhered in that composition. In this sense, an accident can be subsisted in something composed of many things in terms of being whole. ${ }^{98}$ Therefore, the accidents are subsisted in the human soul (i.e., the subtle body) as a whole; through that, the human being is qualified as knower, alive, and obligated in the true meaning.

\subsection{Theology}

A theologian`s views on the central theological subjects such as metaphysics (ilāhiyyāt), prophetology (nubuwwāt), and matters known through revelation (sam 'iyyāt) are the most critical elements of their thought system. Almutakallimūn's opinions on the ontological, epistemological, and physics provide a basis for the central subjects and must coincide with them, as theological subjects are the main goals (maqūṣid) of kalām.

In Taftāzānī`s thought system, theological issues are seen to have significantly affected his approach to the essence of the human soul. Examining his thoughts on the nature of angels, life in the grave, and the resurrection is vital for clarifying his approach to the essence of the human soul.

\subsubsection{The Essence of Angels, Jinn, and Shaytān (Devil)}

Angels are generally accepted as being luminous beings due to the religious texts related to the subject. However, several understandings are found about the meaning of their luminous being in Islamic thought. In other words, different opinions exist about whether angels are immaterial substances or corporeal beings, just like on the matter of the human soul. Scholars' opinions on the essence of angels generally coincide with their division of existent. For example, the philosophers who give 
place to immaterial substances in the division, included angels in the category of immaterial substance. However, dividing the existents into two kinds (i.e., the eternal and temporally created) and considering that all temporally created beings are bodily, the mutakallimūn argued angels to also be subtle corporeal beings. Therefore, what opinions a philosopher has on the essence of angels also enables one to understand their view on the essence of the human soul.

Taftāzānī provided detailed information about the intellectual aspects that philosophers accept as abstracted substances and stated angels in religious texts to correspond to abstracted intellectual and celestial souls in al-mutakallimūn's thoughts. Moreover, the philosophers who accepted the existence of jinn argued them to also be abstracted substances. According to this understanding, djinns can control (tașarruf) and influence bodies composed of elements because they are abstracted substances. On the other hand, the philosophers who believed in the real existence of shayātīn (devils) stated them to in essence be the human faculty of imagination. However, some philosophers have argued djinns and devils to not be separate species but contrarily to be the different names attributed to human souls according to their states after leaving the bodies. After a human soul leaves the body at the time of death, if it is a good existent that followed intellectual instructions, it is called a jinn, while if it is an evil existent that led to bad things, it is called a shayțān. According to Taftāzānī, acknowledging the existence of angels and djinns resulted in Islamic philosophers agreeing both to be immaterial substances. However, they had different approaches to the existence and essence of devils. ${ }^{99}$

Because Taftāzānī made no mention of a category including immaterial being other than God in the division of existents, he accordingly argued angels, djinns, and devils to be corporeal beings. According to him, the large majority of the Muslim community (al-umma) agree that angels are subtle bodies. This approach is confirmed by the literal sense of Qur`ānic verses and tradition (al-sunna). For Taftāzānī, while angels and djinns are subtle bodies with a predominantly air nature, devils are bodies with a predominantly fire nature. Although these three types are composed of four elements, the predominant element of the devil is fire, while this is air for the angels and djinns. Due to the fact that air and fire are extraordinarily transparent and subtle, the angels, djinns, and devils can penetrate very narrow places and are invisible to the eye. ${ }^{100}$ Taftāzānī refused the objection 
that they must be visible due to being bodily. According to him, all possible things depend on God, The Willfully Choosing Almighty, and He can create the perception of vision in some eyes and certain situations as He sees fit. ${ }^{101}$

\subsubsection{The Life in the Grave}

Taftāzānī’s concept of life in the grave shows that he accepts the existence of a soul beyond the sensible body and considers the essential parts as the essence of the sensible body, not the human soul. I explained before how Taftāzānī had attributed two different views on the human soul to al-mutakallimūn in the chapters devoted to the human soul, but that he had not specified which he preferred. His explanations about the life in the grave are essential, as they show that he does not adopt the essential parts as the soul's essence.

For Taftāzāni, both the soul and the sensible body will be exposed to questioning (suāl), punishment ('adhāb), and blessing (ni 'ma) in the grave. But how could this happen while the sensible body is completely decomposed and the soul is separated from the sensible body? He stated two types of life to exist: perfect (kāmil) and imperfect (nāqiș). Even if a human's sensible body is split into parts, the essential parts will remain. God gives these essential parts an imperfect life so that they can feel pain and pleasure. Therefore, the soul has no need to return to the sensible body for the body to be able to feel pleasure and pain. However, the sensible body needs perfect life in order to be exposed to voluntary actions. The human soul needs to return to the sensible body so that perfect life can inhere in it. This will happen after the resurrection takes place. ${ }^{102}$ The existence of the structure for the sensible body is not necessary for life to be subsistent in it. Even if the sensible body is decomposed in the grave, God has the power to create life only in the essential parts, even in just one atom. ${ }^{103}$ However, people of truth do not accept the view that some feelings like pain and pleasure can occur in a sensible body even if no life is created. ${ }^{104}$

Even though the human soul is separated from the body, it continues to have some kind of link with its sensible body during the life in the grave. As is understood from authentic Hadith narrations, the soul hears the voices of those 
who come to visit the grave. The connection between the soul and the essential parts of the sensible body is not entirely broken after death; a kind of link remains between them. This is why visiting the graves is beneficial; at that time, contact and a spiritual flow can take place between the souls of the living human and the dead human. ${ }^{105}$

\subsubsection{The Resurrection}

Taftāzānī's explanations about the resurrection also show that he viewed the essential parts as the essence of the sensible body, not the soul. The essential parts view is required to not fall into the idea of transmigration (tanāsukh). One of the most critical passages indicating Taftāzānī to consider the human soul and the essential parts as different substances follows:

The quickening of the dead (ba'th) means that God quickens the dead from the graves by collecting their essential parts and then returning their souls to them [the essential parts]... We say, "If the second sensible body had not been created from the essential parts of the first body, there would be transmigration." If such a thing [creating the second sensible body from the first sensible body`s essential parts] is called transmigration, it would only be disputed in name. There is no evidence of the impossibility of returning the soul to such a body. On the contrary, whether or not it is called transmigration, the proof shows its [returning the soul to body's] reality. ${ }^{106}$

As seen in this passage, he states the human soul will be returned to the gathered essential parts at the time of the resurrection. This means the soul and the essential parts will be separated from death until the resurrection. His explanations in the chapter devoted to the afterlife in Sharh al-Maqāșid also support his explanations here. ${ }^{107}$

Firstly, a permanent subject must exist that is the object of punishment and reward. As the perceptions reside in this subject (i.e., the human soul), it deserves punishment and reward. Although this soul is a subtle body, it is permanent.

106 al-Taftāzānī, Sharh al-'Aqāid, 68. Whether the bodily resurrection will occur by gathering the essential parts of the sensible body while they are scattered or whether the sensible body will re-exist after its parts become non-existent is debated under three different approaches: (i) the resurrection by gathering separated parts, (ii) the resurrection by bringing them into existence from non-existence, and (iii) the abstention from having an opinion (al-tawaqquf) in this issue. Although the above

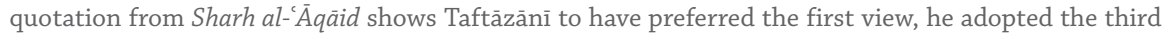
view in his later work Sharh al-Maqāșid, saying the correct approach on this issue to be "tawaqquf". See al-Taftāzānī, Sharḥ al-Maqāṣid, $215 \mathrm{ff.}$ 
Secondly, some parts that existed in the human's sensible body during life in this world must also exist that make the human's sensible body unique. Furthermore, because the human soul will return to these essential parts that constitute the sensible human body, they provide a basis for the bodily resurrection. If one does not accept this, then no identical part exists that could be said to be a sensible human body in this world is the same as the sensible body in the afterlife. In other words, denying the existence of such an identical part in one aspect means accepting transmigration. ${ }^{108}$ As to the sensible body's superfluous parts, no issue is had in assuming that similars of superfluous parts will be created in the sensible body at the time of resurrection.

According to Taftāzānī, who argued the human soul to be deserving of punishment and reward, bringing a rational proof by saying that bodily resurrection is required for performing punishment and reward is impossible because the human essence is only the soul, and its existence in the afterlife is sufficient for punishing and rewarding. However, arguing no rational proof to exist proving bodily resurrection does not mean Taftāzānī denied the bodily resurrection. This is because, according to him, the evidence of the bodily resurrection is not the reason but the revelation (al-wahy). Muslims accept bodily resurrection and believe in it because of the many definitive divine texts, not because of rational proofs. If the bodily resurrection had not been mentioned in the divine texts, no one could prove it based on only the necessity of punishment and reward.

When Taftāzānī stated the evidence of the bodily resurrection to not be reason but definitive divine texts, he was objecting to the approach of the Mu'tazila, as the Mu'tazila had considered reason to necessitate the resurrection of this sensible body that committed good and evil deeds. According to them, the human as a whole (i.e., its essential parts) are obedience and rebelliousness. For Taftāzānī, if the Mu'tazila seek the real subject for deserving reward and punishment, it is the human soul beyond the sensible body. If they see the apparent agent as the subject, they have to argue that all parts of a human during life in the world will be resurrected in the hereafter because, if a human's perceptions and actions reside in the sensible body and is the agent and obligated subject, God will punish and reward that, not the thing resembling it. For instance, if a human being is eaten by a cannibal, the parts of the eaten human will be both the human's and 
the cannibal's parts. In that case, the following questions would arise: In whose body will these parts be resurrected? How will they experience both reward and punishment in the hereafter if one of them did right and the other did evil in the world through those parts? In addition, a person who commits a crime in youth should not be punished because of that crime once they age because the body parts through which that crime had been committed have almost completely changed in old age. Disapproving of the Mu'tazila's approach because of these issues, Taftāzānī argued the cause of punishment and reward to be humans' will, perceptions, and voluntary actions and the agent subject to all of this to not be the sensible body or to be composed of the sensible body and the soul, but to only be the soul. ${ }^{109}$

\section{Conclusion}

Many different views exist on the issue of the essence of man, which is one of the crucial debates in Islamic thought. These views are classified into two main categories: the corporeal soul and the immaterial soul. Although many almuta'akhkhirūn neither clearly nor unequivocally expressed their views on the essence of the human soul in the chapters they devoted to this issue, revealing their opinions is possible based on their views on other issues. When analyzing Taftāzānī's views on epistemology, physics, ontology, and theology coherently, his views also become apparent regarding the essence of the human soul and the concept of man. Defending the existence of the soul beyond the sensible body as being self-evident, Taftāzānī interpreted the inherited tradition in accordance with this thought. Stating the soul being beyond the body to also be self-evident, he abstained from a strict monistic concept of man and got closer to the view regarding the immaterial substance. However, he also did not adopt the conceptual view of abstract substance. Although he stated no definitive rational or scriptural proof to exist that shows whether the human soul beyond the body is a corporeal or immaterial substance, the view most consistent with his concept of physics is that of the subtle body having the same essence as other bodies.

According to Taftāzānī`s conceptualization of man that formed in accordance with his systematic thought, human beings have a sensible body and a soul beyond the sensible body, while only the soul is the essence and truth of the human. The human soul is a subtle body with the same essence as other bodies and is 
composed of atoms. All the qualities of the soul (al-kayfiyya al-nafsāniyya) such as life, knowledge, power, and will are the accidents that have been subsisted within the subtle body and therefore are the attributes of the soul. Because the soul itself is the substratum of these accidents, it is attributed truly not metaphorically as the knower, alive, and mighty. Due to atoms constituting the sensible body not being entirely adjoined, there must be space between atoms of the sensible body and the soul can spread to it by occupying the spaces.

The sensible body is densely compact, composed of atoms and accidents, and has two kinds of parts. The first is the essential parts that exist in it during its life in the world. The second is the superfluous parts that reside in it for a certain period of life. The connection between the human soul as a subtle body and the sensible body as the densely compacted body is provided by another subtle body called the animal soul. The animal soul arises in the heart and spreads throughout the body.

After the soul leaves the body and ascends to the realm of souls, the sensible body dies, and the animal soul and the superfluous parts in it gradually decompose. Accidents such as life and perceptions that were subsisted in the human soul will remain with the soul even after leaving the sensible body. After leaving the body, the human soul continues to perceive both universals and particulars. The soul hears the voices of those visiting its grave because the soul has a connection with its separated sensible body and grave. Even if a person's sensible body decomposes into parts, its essential parts remain, and God can create an imperfect life in them to feel pain and joy in the grave. In other words, although the human soul is separated from the sensible body during its life in the grave, the sensible body can suffer from punishment and enjoy pleasure due to God creating an imperfect life in the essential parts.

Meanwhile, despite the sensible body's decomposition, the human soul continues to be attributed by its qualities such as knowledge, power, life, and perception. Consequently, no obstacle exists in this corporeal soul's suffering punishment or enjoying pleasure after death. In the resurrection, the essential parts of the body will be gathered and the human soul will be returned to them. The soul and the sensible body will be reunited after the resurrection. A human's sensible body in this world and sensible body in the hereafter are similar in terms of their superfluous parts and the same in terms of their essential parts. Because human's essential parts in both worlds are the same, the quickening of the dead and the resurrection are not the same as transmigration. 


\section{Bibliography}

Alper, Ömer Mahir. Aklın Hazzı: İbn Kemmûne’de Bilgi Teorisi. İstanbul: Ayışığı Kitapları Publications, 2004.

Altaş, Eşref. "Fahreddîn er-Râzî̀ye Göre İnsanın Mahiyeti ve Hakikati -Mücerred Nefs Görüşünün Eleştirisi-”. In İnsan Nedir?: İslam Düşüncesinde İnsan Tasavvurlarl, edited by Ömer Türker and İbrahim Halil Üçer, 139-99. Ankara: İLEM Publications, 2019.

Āmidī, Abū al-Ḥasan Sayf al-dīn 'Ali b. Muhammad b. Sālim. Abkār al-afkār fì ușūl al-dīn. Edited by Aḥmad Muhammad al-Mahdī. 5 vols. Cairo: Dār al-Kutub wa al-Wathāik al-Qawmiyya, 2004.

Anșārī, Abū l-Qāsim. al-Ghunya fí al-kalām. Edited by Muṣtafā Hasanain 'Abd al-Hādī. 2 vols. Cairo: Dār alSalām, 2010.

Aristotle. Ruh Üzerine. Translated by Zeki Özcan. İstanbul: Alfa Publications, 2000.

Arkan, Atilla. "Psikoloji: Nefis ve Akıl." In İslâm Felsefesi: Tarih ve Problemler, edited by M. Cüneyt Kaya. İstanbul: İSAM Publications, 2013.

Ash'arī, Abū al-Ḥasan. Maqālat al-Islāmīyīn wa-ikhtilāf al-mușallīn. Edited by Ömer Aydın and Mehmet Dalkılıç. İstanbul: Türkiye Yazma Eserler Kurumu Başkanlığı Publications, 2019.

Attar, Muhammad Fariduddin. "Fahr al-Dīn al-Rāzì on the Human Soul: A Study of the Psychology Section of al-Mabāḥiṭ al-Mašriqiyya fī ‘ilm al-Ilāhiyyāt Wa-l-Ṭabī'iyyāt.” The Master`s Thesis, McGill University Institute of Islamic Studies, 2014.

Avicenna. Ilāhiyyāt. Edited by Ekrem Demirli and Ömer Türker. 2nd ed. 2 vols. İstanbul: Litera Publications, 2013.

Kitāb al-Nafs. Edited by Fazlur Rahman. London: University of Durham, 1959.

Bayḍawī, Qāḍi Nașīr al-Dīn Abū 'Abd Allāh b. 'Umar. Misbāḥ al-arwāḥ fì uṣūl al-dīn. Edited by Saīd 'Abd Allāh Fūda. 'Ummān: Dār al-Rāzī, 2007.

, Țawāli ' al-anwār min mațāli' al-anz̄ōr. Edited by 'Abbās Sulaymān. Beirut and Cairo: Dār al-Jīl and al-Maktabah al-Azharīyah lil-Turāth, 1991.

Bazdawī, Abū al-Yusr 'Alī ibn Muhammad. Ușūl al-dīn. Cairo: al-Maktaba al-Azhariyya li-l-Turāth, 2003.

Biçer, Ramazan. “Şemseddin Semerkandîye Göre İnsan Psikolojisinin Temel Nitelikleri." In Al Farabi IV. International Congress On Social Sciences: Congress Full Text Book, edited by Özlem Ülger and Atabek Movlyanov, 852-62. İksad Publications, 2019.

Bulğen, Mehmet. Kelâm Atomculuğu ve Modern Kozmoloji. Ankara: TDV Publications, 2015.

Cengiz, Yunus. "Two Competing Approaches in the Mu'tazilite View of the Human Being: The Traditions of Abū al-Hudhayl and al-Nażāām." Nazariyat Journal for the History of Islamic Philosophy and Sciences 4, no. 2 (April 2018): 57-73.

Durusoy, Ali. İbn Sînâ Felsefesinde İnsan ve Alemdeki Yeri : Nefs, Akıl ve Ruh. İstanbul: Marmara Üniversitesi İlahiyat Fakültesi Vakfı Publications, 2012.

Erdinç, Ziya. "Klasik Sonrası İslâm Düşüncesinde İnsanın Hakikatine İlişkin Önemli Bir Sorun: Soyut Nefis Tikelleri Bilebilir Mi?". In The Construction of Human, Creed and Space-II: Values and Concepts International and Inter-Disciplinary Symposium on Soul, 429-46. Çanakkale: ÇOMÜ Publications, 2021.

“Teftâzânî̀de Bilen Bir Özne Olarak İnsan”. In İnsan Nedir? İslam Düşüncesinde İnsan Tasavvurları, edited by Ömer Türker and İbrahim Halil Üçer, 243-92. Ankara: İLEM Publications, 2019.

“Teftâzânîdde Bilgi Teorisi”. PhD Dissertation, The Institute of Social Sciences at Sakarya University, 2019. 
Frank, Richard M. “Abū Hāshim's Theory of «States»: Its Structure and Function”. In Actas Do Congressu de Estudios Arabes e Islámicos, 85-100. Leiden: Brill, 1971.

Beings and Their Attributes: The Teaching of the Basrian School of the Mu 'tazila in the Classical Period. Studies in Islamic Philosophy and Science. Albany: State University of New York Press, 1978.

Ghazālī, Muḥammad ibn Muḥammad Abū Ḥāmid. Ihyyā' 'ulūm al-dīn. 9 vols. Jeddah: Dār al-Minhāj, 1432.

Ma 'ārij al-quds fi madārij ma 'rifat al-nafs. Beirut: Dār al-Āfāq al-Jadīda, 1975.

Heemskerk, Margaretha T. “'Abd al-Jabbār al-Hamadhānī on Body, Soul and Resurrection.” In A Common Rationality: Mu'tazilism in Islam and Judaism, edited by Camilla Adang, Sabine Schmidtke, and David Sklare, 127-56. Würzburg: Ergon Verlag in Kommission, 2007.

Ibn al-Malāhịimī, Rukn al-Dīn Maḥmūd Ibn Muhammad al-Khuwārazmī. Kitāb al-Fā 'iq fì uṣūl al-dīn. Edited by Wilfred Madelung and Martin McDermott. Tihrān: Mu'assasah-'i Pizhūhishī-i Ḥikmat va Falsafah-'i Îrān, 2007.

Tuḥfat al-mutakallimīn fĩ al-radd 'alā al-falāsifa. Edited by Hasan Anșārī and Wilfred Madelung. Tihrān: Mu'assasah-'i Pizhūhishī-i Ḥikmat va Falsafah-'i İrān, 2008.

Ibn al-Qayyim al-Jawziyya, Abū 'Abd Allāh Shams al-Dīn Muḥammad b. Abī Bakr. Kitāb al-Rūḥ. Edited by Muhammad Ajmal al-Iṣlāḥī. 2 vols. Mecca: Dār ‘Ālam al-Fawāìd, 1432.

Ibn Fūrak, Abī Bakr Muḥammad Ibn al-Ḥasan. Mujarrad maqālāt al-Shaykh Abī al-Ḥasan al-Ash 'arī. Edited by Daniel Gimaret. Beirut: Dār al-Mashriq, 1987.

İjī, 'Aḍūd al-Dīn. al-Mawāqiffì 'ilm al-kalām. Beirut: ‘Ālam al-Kutub, n.d.

Iṣfahānī, Shams al-Dīn Abū al-Thanā' Maḥmūd Ibn 'Abd al-Raḥman Ibn Aḥmad. Tasdīd al-qawā 'id fī Sharḥ Tajrīd al- 'aqā ìd. Edited by Khālid b. Ḥammād al-'Adwānī. 2 vols. Kuwait: Dār al-Ḍiyā', 2012.

İskenderoğlu, Muammer. "Fakhr al-Din al-Razi on the Immateriality of the Human Soul." Journal of Oriental and African Studies, no. 14 (January 2005): 121-36.

Jurjānī, al-Sayyid al-Sharīf. Hāshiya 'alā Sharḥ al-Mukhtaṣar al-muntahā al-ușūlī. Edited by Muhammad Ḥasan Ismāềl. 3 vols. Beirut: Dār al-Kutub al-'Ilmiyya, 2004.

, Sharh al-Mawāqif fì 'ilm al-kalām. Edited by Ömer Türker. 3 vols. İstanbul: Türkiye Yazma Eserler Kurumu Başkanlığı Publications, 2015.

Juwaynī, 'Abd al-Malik ibn 'Abd Allāh Imām al-Haramayn. al-Shāmil fĩ uṣūl al-dīn. Edited by 'Alī Sāmī Nashshār, Fayṣal Budayr 'Awn, and Suhayr Muhammad Mukhtār. al-Iskandariya: Munsha'āt al-Ma ārif, 1969.

Kitāb al-Irshād ilá qawāți ' al-adillah fĩ uṣūl al-i 'tiqād. Edited by Muhammad Yūsuf Mūsā. Cairo: Maktaba al-Khanjī, 1950.

Kaş, Murat. "Seyyid Şerîf Cürcânî̀de Zihnî Varlık”. PhD Dissertation, Marmara University Social Sciences Institute, 2017.

Ka'bī, Abu'l-Qāsem al-Balkhī al-. Kitāb al-Maqālāt wa ma'ahu 'Uyūn al-masā'il wa al-jawābāt. Edited by Hüseyin Hansu and Rājih Abdulhamīd Kurdī. Istanbul and Amman: KURAMER and Dār al-Fath, 2018.

Korlaelçi, Murtaza. “Gazzâlî̀nin İnsan Anlayışı”. In 900. Vefat Yılında İmam Gazzâlî: Milletlerarası Tartışmalı İlmî Toplantı, 759-86. İstanbul: Marmara Üniversitesi İlahiyat Fakültesi Vakfı Publications, 2012.

Madelung, Wilfred. "Ibn al-Malāhimī on the Human Soul”. The Muslim World 102, no. 3-4 (October 2012): 426-32.

Najrānī, Taqī al-Dīn. al-Kāmil fì al-istiqșā’ fïmā balaghanā min kalām al-qudamā’. Edited by al-Sayyid alMaḥmūd al-Shāhid. Cairo: al-Majlis al-A`lā li-al-Shuūn al-Islāmiyya, 1999. 
Qāḍī 'Abd al-Jabbār. al-Mughnī fí abwāb al-tawhīd wa al- 'adl: al-taklīf. Edited by Muhammad 'Ali al-Najjār and 'Abd al-Halīm al-Najjār. Vol. XI. 20 vols. Cairo, n.d. , Sharh al-Ușūl al-khamsa. Cairo: Maktabatu Wahba, 1988.

Rāzī, Fakhr al-Dīn Abū 'Abd Allāh Muhammad Ibn 'Umar. al-Arba'īn fí 'ușūl al-dìn. 2 vols. Cairo: Maktaba alKulliyyāt al-Azhariyya, 1986. al-Mabāhith al-mashriqiyya fì 'ilm al-ilāhiyyāt wa al-tabī'iyyāt. Edited by M. Mu'tașim-Billāh alBaghdādī. 2 vols. Beirut: Dār al-Kitāb al-'Arabī, 1990. , al-Maṭāilb al-āliyâ min al-îlm al-ilāhī. Edited by Aḥmad Hijāzī al-Saqqā. 9 vols. Beirut: Dār al-Kitāb al-'Arabī, 1987.

, Muhașșal afkār al-mutaqaddimīn wa al-muta 'akhkhirīn min al- 'ulamā' wa al-hukamā' wa al-mutakallimīn. Edited by Ṭāhā 'Abd al-Ra'ūf Sa'd. Cairo: Maktabat al-Kulliyyāt al-Azhariyya, n.d.

, Nihāya al-'uqūl fĩ dirāyāt al-uṣūl. Edited by Saīd 'Abd Allāh Fūda. Beirut: Dār al-Zakhāir, 2015.

Samarqandī, Shams al-Dīn. al-Ṣaḥa 'if al-ilāhiyya. Edited by Aḥmad al-Sharīf. Kuwait: Maktaba al-Falāḥ, 1985. , 'İlm al-äfāq wa-l-anfus. İstanbul: Türkiye Yazma Eserler Kurumu Başkanlığı Publications, 2020.

Shihadeh, Ayman. "Classical Ash`arī Anthropology: Body, Life and Spirit.” The Muslim World 102, no. 3-4 (October 2012): 433-77.

Suhrawardī, Shihāb al-Dīn. "Ḥikmat al-Ishrāq." In Majmū'a-yi muṣannafāt-i Shaykh-i Ishrāq, Vol. II. Tihrān: Pizhūhishgāh-i 'Ulūm-i Insānī wa-Muțāla'āàt-i Farhangī, 1993.

Taftāzānī, Sa'd al-Dīn Mas'ūd b. 'Umar b. 'Abd Allāh "al-Maqāṣid”. In Sharḥ al-Maqāṣid. 2 vols. İstanbul: Maṭba‘a al-Ḥājj Muḥarram Efendi al-Bosnawī, 1305. , Sharḥ al-Maqāṣid fì 'ilm al-kalām. 2 vols. İstanbul: Maṭba'a al-Ḥājj Muḥarram Efendi al-Bosnawī, 1305 , Sharh al- Aqāid al-Nasafiyya. Edited by Aḥmad Hijāzī al-Sakkā. Cairo: Maktabat al-Kulliyyāt alAzhariyya, 1988.

, Tahdhīb al-manțiq wa al-kalām. Edited by 'Abd al-Qadīr al-Kurdī. Cairo: Mațba'a al-Sa'āda, 1912.

Türker, Ömer. "Kelâm Geleneğinde Adudüddin El-Î̂î: Kelâmın Bilimsel Kimliği Sorunu.” In İslâm İlim ve Düşünce Geleneğinde Adudüddin El-Îcî, 299-337. İstanbul: İSAM Publications, 2017.

"Kelam ve Felsefe Geleneklerinin Kesişim Noktasinda Seyyid Şerif Cürcânî." In İslâm Düşüncesinde Süreklilik ve Değişim: Seyyid Şerif Cürcânî Örneği, edited by M. Cüneyt Kaya, 1-61. İstanbul: Klasik Publications, 2015.

“Nefis.” In TDV İslâm Ansiklopedisi, XXXII:529-31. Ankara: TDV Publications, 2006.

Ṭūsī, Naṣīr al-Dīn. Tajrīd al-'aqāid. Edited by 'Abbās Muhammad Ḥasan Sulaimān. al-Iskandariya: Dār alMa ārif al-Cāmi'iyya, 1996.

, Talkhīṣ al-Muhașșal. Beirut: Dār al-Aḍwā', 1985.

Üçer, İbrahim Halil. İbn Sînâ Felsefesinde Suret, Cevher ve Varlık. İstanbul: Klasik Publications, 2017. 